\title{
British women who contributed to research in the geological sciences in the nineteenth century
}

\author{
MARY R. S. CREESE and THOMAS M. CREESE*
}

\section{INTRODUCTION}

A count of articles by women listed in the Catalogue of Scientific Papers, 1800-1900, the nineteen-volume international index brought out by the Royal Society, ${ }^{1}$ produced a collection of almost 4000 titles of papers by about 1000 nineteenth-century women authors. Out of 181 geology papers in this collection, 118 (65 per cent) were by British women (see Table 1, columns 1 and 2). This finding is especially remarkable when considered against the more general background of nineteenth-century women's work in science (at least as judged from women's contributions to the journal literature indexed by the Royal Society). In most fields American workers considerably outnumbered British and published many more papers. ${ }^{2}$ Geology, however, is an exception, with the British dominating the field by a wide margin. This essay discusses a number of the British women of the period who carried out work in geology, and offers some suggestions that go toward explaining their striking prominence among their contemporaries.

They may be grouped into two fairly distinct, though not entirely separate categories. The first comprises the small but fairly continuous progression of self- or privately-taught 'amateurs', for the most part observers, collectors and classifiers, who, along with their far more numerous male counterparts in the naturalist tradirion, were active from the early decades of the century. Those in the second category, the women with formal university training in geology, appeared in increasing numbers from the 1880s onwards, following the establishment of the women's colleges at Cambridge, the improvement of one or two already in existence in London, and the admission of women to some of the other

- Department of Mathematics, University of Kansas, Lawrence, KS, 66045, USA.

This work was supported in part by University of Kansas General Research allocations \# 3179-xx-0038 and 3312-xx-0038. We thank Dr Elisabeth van Houts, Newnham College Archivist, for information from Newnbam College Register and Girton College Register, and Miss Carol R. Bowen, University College London, for information from student records. The passage in note 69 is quoted with the permission of the Principal and Fellows of Newnham College, Cambridge.

1 Catalogue of Scientific Papers, 1800-1900, 19 vols. Compiled by the Royal Society, Cambridge, 1867-1925.

2 Columns 3, 4, 5 and 6 in Table 1 give, for comparison, data for botany and the chemical sciences, two fields that were particularly popular with nineteenth-century women scientists. The exceptional position held by British women in geology is fairly clear; the fraction of papers by them in that field is the largest we have found for any national group within any given field. 
Table 1. Number of women authors and number of papers in geology, botany, and the chemical sciences by regional groupings; from the Catalogue of Scientific Papers, 1800-1900

\begin{tabular}{|c|c|c|c|c|c|c|}
\hline \multirow[b]{2}{*}{ Region } & \multicolumn{2}{|l|}{ Geology } & \multicolumn{2}{|l|}{ Botany } & \multicolumn{2}{|c|}{ Chemical sciences } \\
\hline & $\begin{array}{l}\text { (1) } \\
\text { No. of } \\
\text { authors }\end{array}$ & $\begin{array}{l}(2) \\
\text { No. of } \\
\text { papers }\end{array}$ & $\begin{array}{l}\text { (3) } \\
\text { No. of } \\
\text { authors }\end{array}$ & $\begin{array}{l}\text { (4) } \\
\text { No. of } \\
\text { papers }\end{array}$ & $\begin{array}{l}\text { (5) } \\
\text { No. of } \\
\text { authors }\end{array}$ & $\begin{array}{l}\text { (6) } \\
\text { No. of } \\
\text { papers }\end{array}$ \\
\hline Britain, Ireland & $24(49 \%)$ & $118(65 \%)$ & $67(28 \%)$ & $230(28 \%)$ & $33(26 \%)$ & $96(23 \%)$ \\
\hline $\begin{array}{l}\text { France, Belgium, } \\
\text { The Netherlands }\end{array}$ & $5(10 \%)$ & $8(4 \%)$ & $14(6 \%)$ & $54(7 \%)$ & $4(3 \%)$ & $4 *(1 \%)$ \\
\hline Germany, Austria & $1(2 \%)$ & $1(<1 \%)$ & $6(2 \%)$ & $20(2 \%)$ & $7(6 \%)$ & $24(6 \%)$ \\
\hline Italy & $4(8 \%)$ & $9(5 \%)$ & $4(2 \%)$ & $42(5 \%)$ & $2(2 \%)$ & $3(1 \%)$ \\
\hline Russia, Poland & $6(12 \%)$ & $24(13 \%)$ & $5(2 \%)$ & $26(3 \%)$ & $29(23 \%)$ & $121(29 \%)$ \\
\hline Scandinavia & $2(4 \%)$ & $5(3 \%)$ & $9(4 \%)$ & $22(3 \%)$ & $5(4 \%)$ & $13(3 \%)$ \\
\hline USA, Canada & $7(14 \%)$ & $16(9 \%)$ & $118(49 \%)$ & $398(48 \%)$ & $42(33 \%)$ & $147(36 \%)$ \\
\hline Other & - & - & $19(8 \%)$ & $29(4 \%)$ & $4(3 \%)$ & $6(1 \%)$ \\
\hline Total & $\overline{49}$ & $\overline{181}$ & $\overline{242}$ & $\overline{821}$ & $\overline{126}$ & $\overline{414}$ \\
\hline
\end{tabular}

* The fifteen publications by Marie Curie during the period were classed as physics and are therefore not included in the data given in this table.

universities. ${ }^{3}$ Since this second category forms a group whose lower time boundary is rather clearly definable, the distinction between 'amateur' and the person with formal training in geology can be drawn more sharply with women than with men, among whom the divergence of a 'professional' group was very gradual. ${ }^{4}$ Although a number of the university-trained women published only one or two papers as students, some became productive research geologists. Their appearance marked the beginning of a remarkable change in the pattern of women's participation in geological research (see Figure 1), and their work, carried out during the last fifteen years of the century, accounted for no less than half of the nineteenth-century journal publications in geology by British women.

The opening of universities to women signalled the removal of only some of the obstacles facing women geologists, however, and so the members of the new group kept a certain amount in common with the older one, to a significant extent facing similar problems of isolation and limited acceptance. We outline the careers of four women from the later part of the century, who, despite the handicaps they faced, were clearly outstanding, although they have received little attention in accounts of nineteenth-century women scientists. Also described is the work of some from the earlier decades whose

3 Margaret J. Tuke, A History of Bedford College for Women, 1849-1937, London, 1939, especially 18, 127-8, 138-9; Rita McWilliams-Tullberg, Women at Cambridge. A Men's University-Though of a Mixed Type, London, 1975; Barbara Stephen, Emily Davies and Girton College, London, 1927.

4 See, for example, Jean G. O'Connor and A. J. Meadows, 'Specialization and professionalization in British geology', Social Studies of Science (1976), 6, 77-89, and Roy Porter, 'Gentlemen and geology : the emergence of a scientific career, 1600-1920', The Historical Journal (1978), 21, 809-36. 


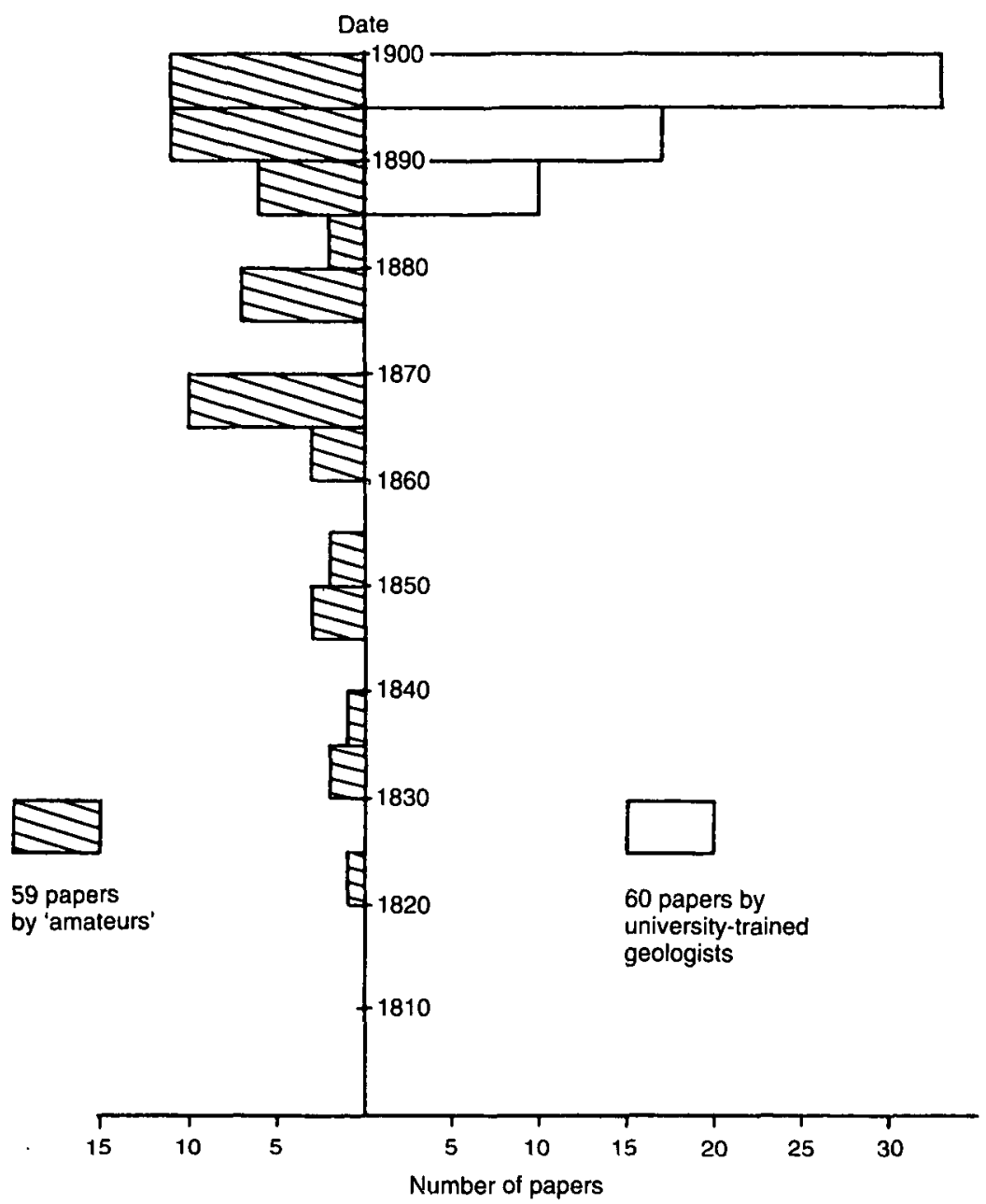

Figure 1. Number of geology papers published by British women, 1800-1900 (in five-year intervals), by those with formal training on the right of the vertical axis, by 'amateurs' on the left. (Data from the Catalogue of Scientific Papers, 1800-1900; one communication by Mary Anning added.)

contributions were of special interest in the then rapidly developing field. ${ }^{5}$ Others are mentioned briefly in the text or listed in Appendix 1.

\section{THE 'AMATEURS'}

A number of talented wife-assistants of some of the famous men geologists of the early nineteenth century are known to have made contributions to various aspects of their

5 To gain a somewhat fuller picture of British women's contributions in the early years of the century we have included in the discussion three women from that period who were notable but do not appear in the Royal Society index. These are Benett, Anning and Philpot. In the interest of consistency in international and interdisciplinary comparisons, they have not been added to the data lists in Table 1. 
husbands' work, treating it much as a family concern. However, although effective in the tasks they undertook (very often technical drawing), they appear for the most part to have settled for roles as general assistants. ${ }^{6}$

Independent work by women in nineteenth-century geology probably begins with Etheldred Benett (1776-1845), , who has been described as 'the most distinguished of early women workers in geology' in Britain. ${ }^{8}$ She was born in Tisbury, Wiltshire, the daughter of a country squire. Her interest in fossils, pursued over a period of thirty-four years, is said to have been stimulated by her brother-in-law, A. B. Lambert, a man of wide scientific interests and a keen collector of fossils and minerals. Being financially independent, unmarried, and free from major family commitments, she spent much of her time and energy on fossil collecting, and by 1813 had established an extensive cabinet. Many of the specimens she discovered were illustrated in James Sowerby's Mineral Conchology of Great Britain (1812-20), a major work in which the great majority of the many species included were new to science, accurately figured, and given Linnean names. Sowerby went even further in making Benett's work available to the public, and in 1816, withour telling her or receiving permission, published a bed-by-bed description she had given him of the Upper Chicksgrove quarry at Tisbury. Based on material she had collected with the help of the quarry foreman, John Montague, it was one of the earliest bed-by-bed quarry

6 Both Mary Morland Buckland (1797-1857), wife of William Buckland, and Mary Ann Woodhouse Mantell (fl. 1820s and 1830s), wife of Gideon Mantell, assisted their husbands in illustrating, collecting and, in Buckland's case, writing. Even before her marriage, Mary Morland had been an active fossil collector and she had prepared illustrations for the work of the French palaeontologist, Baron Georges Cuvier. Buckland's Bridgewater Treatise, Geology and Mineralogy Considered with Reference to Natural Theology (1836), included many illustrations prepared by his wife. Mary Mantell drew the forty-two plates of fossils which embellished Mantell's well-received Fossils of the South Downs: or Illustrations of the Geology of Sussex (1822), and it was she who discovered the first of the iguanodon fossil teeth which led to Mantell's important 1825 paper in the Philosophical Transactions announcing the discovery of a new giant reptile group. Though an enthusiastic supporter of her husband's geological work throughout twenty years of marriage, she was finally forced to leave him when his preoccupation with geology displaced in his priorities both his family and his medical practice. Charles Lyell and Roderick Murchison also had assistance from their wives in their geological work. Mary Horner Lyell (1808-73), daughter of the geologist Leonard Horner, became an accomplished conchologist during the course of her work with Lyell, whom she frequently accompanied on expeditions. She also read and translated for him and managed his correspondence, his eyesight being poor. Charlotte Murchison (1789-1869) assisted in collecting, cataloguing and illustrating. Indeed, Murchison's marriage to Charlotte Hugonin in 1815 marked a turning point in his life, and it was to some extent her influence that drew him away from his first career in the army and into scientific pursuits. Lyell's description of Mrs Murchison during the 1828 Lyell-Murchison trip through the Auvergne and Italy makes clear her assistant's role, however: 'She is very diligent, sketching, labelling specimens and making out shells, in which she is an invaluable assistant. She is so much interested in the affair, as to be always desirous of keeping out of the way when she would interfere with the work.' (For Buckland and Mantell see, respectively, Mrs [Elizabeth O. Buckland] Gordon, The Life and Correspondence of William Buckland, D.D., F.R.S., New York, 1894, especially 90-3, and Edwin H. Colbert, Men and Dinosaurs. The Search in Field and Laboratory, New York, 1968, 15-23. For Lyell and Murchison see Edward B. Bailey, Charles Lyell, New York, 1963, especially $68-9,95,101-3,144-5,156$; the passage quoted is on 68-9.) Two other women who assisted in early nineteenthcentury geological work were Lady Mary Cole and Jane Talbot, of Gower, Wales, who was frequently consulted by Buckland (see Patricia Phillips, The Scientific Lady. A Social History of Women's Scientific Interests 1520-1918. New York, 1990, 184.

7 H. S. Torrens, 'Women in geology. 2 - Etheldred Benett', Open Earth (1983), 12-13.

8 H. B. Woodward, The History of the Geological Society of London, London, 1907, 118-19. 
sections published in England. ${ }^{9}$ Although barred from membership of the London Geological Society, she presented it with a preliminary report of this study in 1815 , and followed a year later with a manuscript volume giving a more detailed description of the fossils found in each bed.

Benett had an active correspondence with many of the leading men geologists of the time, including William Buckland and Gideon Mantell, with whom she discussed her fossil finds, and George Greenough, to whose Geological Map of England and Wales (Geological Society, 1819) she enthusiastically contributed stratigraphical information for the Wiltshire region. Her plan to publish in 1818 a stratigraphic catalogue of the species in her own large collection was postponed because her brother's entry into politics and his subsequent election in 1819 as MP for South Wiltshire temporarily divided her interests. The work finally appeared in 1831 as a section in the third volume of Sir Richard Colt Hoare's The History of Modern Wiltshire; she reissued it separately in the same year, with some revision, as A Catalogue of the Organic Remains of the County of Wilts. It was widely noted at the time and contained a number of new taxa which she was the first to illustrate. Particularly noteworthy were her descriptions and illustrations of several species of Upper Greensand sponges. Many of her best specimens were presented to individual geologists and to public museums when she felt that this would benefit science. Some went to a museum in St Petersburg, and, in return, the Tsar, assuming from her first name that she was a man, had the University of St Petersburg give her an honorary doctorate of Civil Law. Her solid achievements in collecting, strata identification, and publication of original work were unmatched for a woman of her time.

From the same period, but now better remembered than Etheldred Benett because of the more spectacular nature of their finds, were the fossil collectors of Lyme Regis, Dorset. These were the three Philpot sisters, especially Elizabeth (1780-1857), and their younger friend, Mary Ann Anning (1799-1847). Over the course of the early years of the century the Philpors put together an extensive museum of exceptionally fine fossil fishes collected from the rich local lias beds. ${ }^{10}$ William Buckland, who made many references to Elizabeth Philpot in his published papers, regularly examined this collection, and the Swiss geologist Louis Agassiz found specimens there that surpassed all his expectations. Agassiz made considerable use of them during the preparation of his five-volume work, Recherches sur les poissons fossiles (1833-44), and in recognition of what he felt were Elizabeth's notable services to fossil ichthyology named a species, Eugnathus philpotia. Mary Anning, ${ }^{11}$ a carpenter's daughter with little formal education, searched for fossils to eke out her family's income. As a small child she had accompanied her father on such searches, and he evidently taught her how to use tools. She developed remarkable skill, not only in finding fossils, but in extracting them. Following her father's death when she was ten, she

9 The description appeared, with additional notes by Sowerby, in vol. 2 (pp. 58-9) of his Mineral Conchology. Torrens, op. cit. (7), 12, has pointed out that Benett was clearly influenced by the pioneering work during the early years of the century of William Smith, a surveyor, who led the way in showing that strata could be identified by their fossil content; Smith's ideas quickly became fairly widely known.

10 See J. M. Edmonds, 'The fossil collection of the Misses Philpot of Lyme Regis,' Dorset Natural History and Archaeological Society Proceedings (1976, 1978), 98, 43-8.

11 Dictionary of National Biography, London, 1921 (hereafter DNB), xxii, supplement, 51-2; Gordon, op. cit. (6), 113-16; Phillips, op. cit. (6), 183. 
continued collecting on her own extremely successfully, supporting herself and her mother by this work, and making several sensational finds. She discovered the fossil skeleton that William Conybeare identified as an ichthyosaurus in 1811, the first specimen to be found in Britain, and she received for it the sum of $£ 23$ from a London museum. She followed this up in 1824 with the entire skeleton of a previously unknown saurian, named plesiosaurus by Conybeare. Great care, patience, and long labour were required in the work; it took her ten years to extract the plesiosaurus, its position in the lias being accessible only at low water. Auctioned off to the highest bidder, it brought her $£ 150$, a considerable sum at the time. In 1828 she found a pterodactylus, described by Buckland. Less spectacular than the saurians but of great importance for collections, were her many discoveries of fossil fishes and molluscs, including numerous cephalopods with their fossil ink bags.

Anning was one of the most notable collectors of the early nineteenth century. ${ }^{12} \mathrm{Her}$ discoveries, like those of Elizabeth Philpot, formed an extremely important contribution to the emerging fossil record on which Buckland, Conybeare, Henry de la Beche and other great figures of the 'golden age' of British geology based their new theories. For more than thirty years she functioned as one of the most skilful and expert field workers in the country, and her services were eventually rewarded with a small government annuity which Buckland succeeded in obtaining for her. Fifteen years after her death the Fellows of the Geological Society placed a stained-glass window to her memory in the church at Lyme, and a posthumous portrait of her, executed in 1850, hangs in their meeting rooms in Burlington House, London.

Apart from some letters, however, Anning left no written records of her activities. Hence her contributions have often been ignored in accounts of the development of the subject, and her work has been incorporated into that of the men geologists with whom she collaborated so closely. Later writers of geological history have tended to omit her name from discussions of the discoveries she made; the ichthyosaurus and plesiosaurus have become simply 'Conybeare's discoveries'. ${ }^{13}$ A short note by Anning to Edward Charlesworth, editor of the Magazine of Natural History, concerning details of Hybodus fossils, is the only piece of her writing we have yet come across that was published during her lifetime, but like her other extant letters to her geologist acquaintances, or more frequently to their wives, it makes plain the fact that her involvement in geological work went well beyond that of rude fossil-hunter. ${ }^{14}$ To her father the fossils had been only

12 Woodward, op. cit. (8), 115.

13 See, for example, Leonard G. Wilson, 'The intellectual background to Charles Lyell's Principles of Geology, 1830-1833', in Toward a History of Geology (ed. Cecil J. Schneer), Cambridge, Mass., 1969, 426-43, especially $435-6$.

14 Mary Anning, 'Note on the supposed frontal spine in the genus Hybodus', Magazine of Natural History (1839), $12(3$, n.s.), 605 . The note reads as follows:

In reply to your request I beg to say that the hooked tooth is by no means new; I believe M. De la Beche described it fifteen years since in the Geological Transactions, but I am not positive; but I know that I then discovered a specimen, with about a hundred palatal teeth, as I have done several times with different specimens. I had a conversation with Agassiz on the subject; his remark was that they were the teeth by which the fish seized its prey,-milling it afterwards with its palatal teeth. I am only surprised that he has not mentioned it in his work. We generally find Ichthyodorulites [defensive finbones] with them, as well as Cartilaginous bones. 
curiosities worth money, but she, thanks to her own native abilities and her friendships with the leading geologists of the time, had, over the years, built up a very fair knowledge of the anatomy and classification of fossil saurians and fishes. ${ }^{15}$ She was well known to geologists in Europe as well as in Britain ('I am well known throughout the whole of Europe'), ${ }^{16}$ and, like the other Lyme Regis women collectors, was quite aware of the significance and importance of the specimens she was discovering, often before the men geologists had examined them. ${ }^{17}$

Two other British women who made contributions to early nineteenth-century geology were Maria Graham and Barbara, Marchioness of Hastings. Maria Graham (1785-1842) ${ }^{18}$ (afterwards Lady Callcott) was a very productive author, who became well-known for her travel books, histories, and children's stories. The daughter of Rear Admiral Dundas, she met Captain Thomas Graham on her first long voyage to the East in 1809 and married him shortly after they landed in India. In 1822 she accompanied him on his own ship bound for Brazil and then Valparaiso, Chile. However, Graham died of fever off Cape Horn. When Mrs Graham arrived in Valparaiso she was lent a cottage by friends, and, staying on there for a year in the British community, came to experience first-hand the Chilean earthquake of 1822.

Her account of that event is one of the earliest detailed and accurate reports of the spectacular effects of major seismic activity. Of particular interest were her observations of the rise in the level of the coastline accompanying the earthquake, recorded in her Journal of a Residence in Chile, during the Year 1822 (1824). At the request of $\mathrm{H}$. Warburton, vice-president of the London Geological Society, she supplied an extract from this journal for publication in the society's Transactions. ${ }^{19}$ The idea of massive uplift of major blocks of land as the result of seismic activity was far from universally accepted then or for some time afterwards. About ten years later Charles Lyell quoted her account at some length in his Principles of Geology (1830-33), and following the publication of the latter work George Greenough, in a presidential address to the Geological Society, launched a vigorous attack on Mrs Graham and her report. He was, he rather condescendingly affirmed, 'deeply sensible of the honour that lady conferred on the Society by her obliging compliance with the request which elicited her narrative, and it is only the importance of its contents which could induce me to subject them to the test of rigid examination ${ }^{2}{ }^{20}$ Greenough was quite unwilling to accept the possibility of a substantial

15 W. D. Lang, 'More about Mary Anning, including a newly found letter', Dorset Nat. Hist. Soc. Proc. (1950), 71, 184-8. See also W. D. Lang, 'Three letters by Mary Anning, fossilist of Lyme', ibid. (1945), 66, 169-73.

16 Remark by Mary Anning to the King of Saxony, on his visit to Lyme Regis (1844), quoted by Gordon, op. cit. (6), 115 .

17 Edmonds, op. cit. (10), 45 .

18 DNB, iii, 710 ; H. J. Rose, A New General Biographical Dictionary, London, 1850, entry reproduced in British Biographical Archive, microfiche edn (ed. Paul Sieveking), London, 1984, no. 351; Jane Robinson, Wayward Women. A Guide to Women Travellers, Oxford, 1990, 44-6.

19 Maria Graham, 'An account of some effects of the late earthquakes in Chili', Transactions of the Geological Society (1824), 1, 413-15.

20 See the three-part article, 'On the reality of the rise of the coast of Chile in 1822, as stated by Mrs. Graham', American Journal of Science and Arts (1835), 28, 239-47. This article includes a reprinting of Mrs Graham's 1824 account in the Transactions of the Geological Society, Greenough's presidential address, and Graham's reply to the latter; the quotation appears on p. 240 ; italics added. 
uplift of the coastline along an extent of many miles, and he proceeded to ridicule Mrs Graham's ability to draw trustworthy conclusions about scientific matters, even questioning the veracity, as well as the accuracy, of almost all her observations. Astonished and indignant at this blatant attack, Mrs Graham (by then Lady Callcotr) responded promptly. She addressed to the members of the Society a well-argued, point by point rebuttal in which she very adequately defended her original statements, pointing out the unjust insinuations, selective omissions of important details, errors and inconsistencies in Greenough's 'rigid examination' ${ }^{21}$

Commenting on Maria Graham's work a century later, Charles Davison came down on her side of the dispute, describing her as 'a close and careful observer' whose attention to detail 'creates confidence in Mrs Graham's important observations on the rise of the adjoining coast'. Davison concluded that, although some conflicting testimony was later presented, 'her observations clearly imply an actual elevation of the solid crust, though the extent of the coast so affected, so far as it does not rest on her own authority, may remain in doubt ${ }^{\prime 2}{ }^{22}$ Graham's report concerned no quiet backwater but related directly to central questions that were of major interest to the leading geologists of the time. ${ }^{23}$

Barbara, Marchioness of Hastings $(1810-58),{ }^{24}$ the only child of Henry Edward Yelverton, Baron Grey of Ruthin, became Baroness Grey of Ruthin at age one when her

21 The following brief extract gives the flavour of Mrs Graham's well-orchestrated counter-attack. She wrote here in the third person:

Mr. Greenough mentions Mrs. Callcott's published journal, and accounts for the dead fish on the shore [Journal, p. 331] by an imaginary storm. Common candour would have led that gentleman to have stated that, in that very journal, it is distinctly printed, that a 'delightful and calm moon-light night followed a quiet and moderately warm day' [ibid., 305].

Mr. Greenough says, further in p. 18 of his address - 'some muscles [sic] and oysters still adhere, she says, to the rocks on which they grew : but we do not know the nature of these rocks, whether fixed or drifted.' Mrs. Callcort was ignorant that there were, or might have been, drifted rocks, until she learned it from Mr. Greenough; for much as she has been at sea, she never met with one. The rocks at Quintero, and at Valparaiso, are of grey granite, and where they lift themselves through the sand and shingle of the beach, they give the notion of bald mountain tops. At all events, they are fixed sufficiently to have caused the wreck of more than one Spanish ship of war; and when she saw them the morning after the Earthquake, that on which the wreck of the Aquila lay, was certainly so far above the water, that the vessel could be approached dryshod, which had never happened before, even at the lowest tides. The beds of muscles [sic], of other shellfish, and of sea-weed, were equally rocks of grey granite, fixed far below the sands of the ocean. These circumstances are stated in the published journal: but $\mathrm{Mr}$. Greenough has suppressed them, and many others of the like nature, particularly the notice of some rocks and stones, that the lowest tides never left dry, but now have a passage between them and the low-water mark, sufficient to ride around without difficulty, p. 313 . (Graham, op. cit. (20), 244.)

22 Charles Davison, The Founders of Modern Seismology, Cambridge, 1927, 34-6.

23 D. E. Allen in, 'The women members of the Botanical Society of London; 1836-1856', BJHS (1980), 13, 240-54, nore 14 on 253, voiced some dissatisfaction with Valerie Appleby's claim that Maria Graham was the first woman to have a paper published by the Geological Sociery (Appleby, 'Ladies with hammers', New Scientist (1979), 84, 714-15). Allen pointed out that Graham's contribution was an extract from a letter written by her to the vice-president and was not read before the Society. As an extract from her published journal, however, supplied at the vice-president's request, presumably for publication in the Society's Transactions because it concerned a matter of considerable current interest, one might perhaps argue that it came close to being in the nature of an invited paper.

24 See Nicholas Edwards, 'The Hastings Collection', Journal of the Society for the Bibliography of Natural History (1970), 5, 340-3. 
father died. In 1831 she married George Augustus Rawdon Hastings, second Marquis of Hastings. She was known especially for the 'Hastings Collection', several thousand fossil specimens from localities in Britain and Europe, now in the British Museum. Although she bought much of the material from dealers, she herself assembled the large collection of fossils from Hordle and Beacon Cliffs on the Hampshire coast. Widowed in 1844, she soon after married Captain Hastings Reginald Henry, RN, and in 1845 settled at Efford House, between Milford and Lymington, where she proceeded, over the course of six years and with help from local people, to collect fossils from exposed beds and to work out the detailed stratigraphy of the area. Existing accounts were inadequate and the situation along the coast was continually changing because of sea erosion and cliff falls which obscured the details of the stratigraphy from the short-term observer. Her extended observations resulted in the preparation of a coloured, scale-drawn section of the beds on which she based her main papers, ${ }^{25}$ and by means of which she was able to record the stratigraphic locations of her fossil finds. She went about her work with great skill and patience: the eminent palaeontologist Richard Owen commented on the extremely fragile and crumbly character of some of the most valuable of her finds - crocodile skulls and turtle shells when they were first extracted from a sand stratum. He noted the care with which she had 'readjusted, cemented and restored them to their original condition ${ }^{26}$ As she stated in her 1853 paper, Hastings' purpose in recording her observations was to help build a comprehensive picture of tertiary stratigraphy, which depended on local observations of this type. Her papers were the first accurate stratigraphical accounts of Hordle and Beacon Cliffs, and have remained among the best. Further, the combination of these writings and her important collection of fossil vertebrates constituted an exceptionally fine contribution to the geological knowledge of the locality. ${ }^{27}$

Both Graham and Hastings were clearly talented and highly capable observers, but while Graham made no claim to being a member of the geological community, the Marchioness saw herself as a serious student of tertiary stratigraphy. Compared with those of many of her male contemporaries, her contributions, though of high quality, were slight. However, her social position and the extent of her commitment to her work ensured her a reasonable reception in at least the more open of the scientific groups. She was able to present a short paper and exhibit her turtle shell and crocodile skull fossils at the British Association meeting at Oxford in $1847 ;^{28}$ on the occasion Richard Owen proposed to name the fossil skull discoveries Crocodilus Hastingsiae in her honour.

Five other amateur women geologists, Elizabeth Carne (1817-73), Elizabeth Hodgson (1814-77), Charlotte Eyton (fl. 1860s and 1870s), Agnes Crane (b. 1852), and Sydney Mary Thompson (d. 1923), published papers in scientific journals throughout the latter half of

25 Marchioness of Hastings, 'Description géologique des falaises d'Hordle, et sur la côte de Hampshire, en Angleterre', Bulletin de la Société Géologique de France (1851-52), n.s. 9, 191-203; 'On the tertiary beds of Hordwell, Hampshire', Philosophical Magazine (1853), 6, 1-11.

26 See R. Owen, 'On the fossils obtained by the Marchioness of Hastings from the freshwater Eocene beds of Hordle Cliffs', Reports of the British Association for the Advancement of Science (1847), pt 2, 65-6.

27 Edwards, op. cit. (24), 342.

28 Marchioness of Hastings, 'On the freshwater Eocene beds of Hordle Cliff, Hants', Reports of the British Association for the Advancement of Science (1847), pt 2, 63-4. See also Owen, op. cit. (26). 
the century. All were middle-class women in comfortable circumstances; Carne, Eyton and Crane had fathers who were well-known naturalists who shared their interests with their daughters. Elizabeth Carne's father was a noted geologist and a Fellow of the Royal Society. From him she inherited a considerable mineral collection along with a substantial fortune. Her three papers on the geology of Cornwall, reporting studies carried out in the 1860s, appeared in the Transactions of the Royal Geological Society of Cornwall. Charlotte Eyton, the daughter of Thomas Campbell Eyton, a well-known Shropshire naturalist, published six notes and papers (mainly concerning investigations of glacial formations) in the Geological Magazine between 1866 and 1870; she also wrote a monograph, Notes on the Geology of North Shropshire (1869). Elizabeth Hodgson, of Ulverston, Lancashire, brought out eight papers on the geology of the Lake District, the first, a description of fossils from iron ore mines near Ulverston, appearing in the Quarterly Journal of the Geological Society in 1863 and most of the others in the Geological Magazine over the course of the following seven years. ${ }^{29}$

Agnes Crane and Sydney Thompson (later Madame Christen), though contemporaries of the first generation of university-trained women geologists, belong to the continuation of the early amateur group which stretched into the last decades of the nineteenth century and beyond. Thompson was for many years an active member of the Belfast Naturalists' Field Club. Stimulated by the work of Percy Kendall on the glacial geology of Yorkshire, she and other members of the Belfast Field Club carried out original work on the glacial deposits of Northern Ireland, especially the collecting and naming of erratics with a view to determining the direction of ice flow. Her writings appeared in the Irish Naturalist and the reports of the Belfast Field Club between 1894 and 1906. Agnes Crane was the only daughter of Edward Crane, Fellow of the Geological Society and chairman of the Brighton Public Museum sub-committee. Her special interest was recent and fossil brachiopoda, and much of her work was done in collaboration with Thomas Davidson, an authority in this area. She assisted in the preparation for publication of Davidson's posthumous memoir on the recent brachiopoda, ${ }^{30}$ and published five articles of her own, mainly in the Geological Magazine, and the Proceedings of the Brighton Natural History Society, between 1877 and 1895. Crane travelled widely, on the Continent and in North and South America, and was one of thirteen women who presented papers at the separate women's sessions of the World's Congress of Geology, organized as part of the Columbian Exposition in Chicago in $1893 .{ }^{31}$

For the most part, the contributions of the nineteenth-century women 'amateurs', from Benett and Anning in the early decades of the century to Crane and Thompson in the 1890s, were accepted by their men colleagues fairly readily, in Anning's case eagerly. The modest

29 For Carne see the DNB, iii, 1044; for Eyton see J. F. Kirk, A Supplement to Allibone's Critical Dictionary of English Literature, 2 vols., Philadelphia, 1891, reproduced in British Biographical Archive (1984), no. 386; for Hodgson see the obituary in the Journal of Botany (1878), 16, 64.

30 Charles Davidson, 'A monograph of recent brachiopoda', Linnean Society of London Transactions, ser. 2, Zoology (1886-88), 4, 248 pp.

31 For Thompson see the obituary by G[renville] A. J. C[ole], 'Madame Christen', Geological Magazine (1923), 60, 478-9; for Crane see Who's Who in Kent, Surrey and Sussex, Cox's County Series, London, 1911, reproduced in British Biographical Archive (1984), no. 278. 
efforts of Hodgson, Crane, Thompson and the few other amateurs from the later years of the century appear to have fitted reasonably comfortably into the work of the regional and amateur scientific groups in association with which they functioned, even if women's presence in the national society was still unacceptable. Maria Graham's writings were an exception. Despite her protest of 'ignorance of the science of geology' and 'consequent indifference to all theories connected with it' ${ }^{32}$ she had, even if unintentionally, interjected her observations and immediate interpretations into a theoretical area that was so controversial that strong reaction from conservative opposition was hardly surprising.

By the late 1880s, with the appearance of the first generation of university-trained women, the picture of women's activity in geology changes dramatically. Indeed, the substantial contributions of the most outstanding members of the later group to a large extent eclipse the work of the 'amateurs' of the older tradition.

\section{THE POST-1880 'PROFESSIONAL' GEOLOGISTS}

Of the twelve women geologists listed in Appendix 1 who are known to have had university training, eight were students at Cambridge, three at University College London, and one at Oxford. Four of them were especially outstanding and received notable honours and awards during their lifetimes. Two of these four, Ogilvie Gordon and Raisin, trained at University College.

Maria Ogilvie Gordon (1864-1939) ${ }^{33}$ was born in Aberdeen, the daughter of a Scottish educator. Though initially a student of piano, she had from an early age been interested in geology and natural history. In 1890 she took a B.Sc. at University College specializing in geology, zoology and botany, and winning a gold medal for zoology and comparative anatomy. She then attempted to get into Berlin University, but, despite the efforts on her behalf of an influential friend, ${ }^{34}$ she failed to break through the barrier against women. She was accepted at Munich, however, as a student of the palaeontologist von Zittel and the zoologist Hertwig, and she spent four years there (1891-95) specializing in recent and fossil corals. ${ }^{35}$ Her London D.Sc. (1893) was the first in geology awarded to a woman, and the

32 Graham, op. cit. (20), 245.

33 See the obituaries by Julius Pia, 'Maria Marilda Ogilvie Gordon', Mitteilungen der Geologischen Gesellschaft in Wien (1939), 32, 173-86, by E. B. Bailey, 'Maria Ogilvie Gordon, D.B.E.', Nature (1939), 144, 142-3, and by E. J. G., Quarterly Journal of the Geological Society (1946), 102, pp. xl-xli.

34 This was most likely Baron Ferdinand von Richthofen, then professor of physical geography at the University of Berlin.

35 Much to Ogilvie's disappointment, the mineralogist Paul Heinrich Groth declined to admit her to his laboratory. Permission for individual women to audit courses at the University of Munich was first granted formally by the authorities only in 1896 ; James Albisetti has noted that the first woman to take classes there was the English geology student Ethel Skeat (see below) who also worked under von Zittel (James C. Albisetti, Schooling German Girls and Women. Secondary and Higher Education in Nineteenth Century Germany, Princeton, 1988, 278). It would seem likely, therefore, that Ogilvie went to Munich in 1891 as a private student of von Zittel and Hertwig. Even earlier (probably in 1886) the Russian student Evgeniia Solomko (see below) had been sympathetically received by von Zittel. He arranged for her to listen to his lectures through an open door in a room next to the auditorium where the German male students sat. Solomko took the complete course of 
Ph.D. in geology she received from the University of Munich (1900) was the first given a woman by that institution. She passed the Munich examinations with distinction in zoology, geology and palaeontology.

Her particular interest throughout her life-long career in geology, from her student days onwards, was the tectonic structure of the South Tyrol, an area of great geological complexity, to which she was introduced in 1891 by Baron Ferdinand von Richthofen. That summer he and his wife took Maria on a month-long excursion into the Dolomites, and she was immediately overwhelmed and captivated by the mountains. Von Richthofen, who had himself carried out the geographical mapping of the region, suggested to her that she investigate the St Cassian, Cortina d'Ampezzo and Schluderbach areas in detail. She began in the autumn of the same year, and proceeded with an initial programme of two years of very difficult and complicated field work without further help or guidance. Her study of the Wengen and St Cassian strata formed the basis of her D.Sc. dissertation and was published in the Quarterly Journal of the Geological Society in 1893. A paper on coral in the Dolomites followed in 1894, and three years later she brought out two major monographs reporting the results of her work on recent and fossil corals. ${ }^{36}$ Von Richrhofen had explained the irregular disposition of the triassic dolomites in the southern Tyrol in terms of Darwin's theory of coral atolls. Without losing his friendship, Ogilvie Gordon questioned this interpretation and put forward the suggestion that most of the irregularities were attributable to complex and hitherto unrecognized folding movements cut by thrusts, ideas developed in the long series of papers she published in British and Austrian journals over a period of forty years, from the late 1890s onwards. She brought together the results of her first twenty years' work in a comprehensive two-volume monograph on the stratigraphy, tectonics and palaeontology of the South Tyrol, which was published in 1927. ${ }^{37}$ Described as 'a monument in the field of Alpine geology', without which 'nobody will ever think of starting work upon this area ${ }^{\prime 38}$ it was the product of much physical as well as mental labour, since the mountaineering challenges involved were considerable. Her major result was the demonstration of the existence of two series of tectonic movements, occurring at different periods and acting in different directions; she interpreted the reef-like appearance of many of the present-day dolomite mountains in terms of these

lectures and also had full access to the Palaeontological Museum with its coral collection, her special interest (D. V. Nalivkin, Nashi Pervye Zhenshchinye-geologi [Our First Women Geologists], Leningrad, 1979. We thank Alla Ivanovna Polekutina, Institute of the History of Science and Technology, Academy of Sciences, Moscow, for telling us about Nalivkin's book).

36 See Maria M. Ogilvie, 'Contributions to the geology of the Wengen and St. Cassian strata in the southern Tyrol', Quarterly Journal of the Geological Society (1893), 49, 1-77; 'Coral in the "dolomites" of South Tyrol', Geological Magazine (1894), 1, 1-10, 49-60; 'Die Korallen der Stramberger Schichten', Palaeontographica (1897), Suppl. 2, Abth. 7, pp. 73-282, i-iv; 'Microscopic and systematic study of madreporian types of corals', Philosophical Transactions, B (1897), 187, 83-345.

37 Maria Ogilvie Gordon, Das Grödener-, Fassa-, und Ennerberggebiet in den Südtiroler Dolomiten. Geologische Beschreibung mit besonderer Berucksichtigung der Ueberschiebungscheinungen, Vienna, 1927. The work had been almost ready for publication in 1914, when, with the outbreak of war, Ogilvie Gordon had to return to Britain, leaving the manuscript in Munich. By the time she went back in 1920 it had disappeared and she had to rewrite it entirely.

38 Wilhelm Solomon-Calvin, 'The Dolomites of South Tyrol', Nature (1928), 121, 83-5, a review of the monograph (tr. L. R. Cox). 
relatively late tectonic events. Her palaeontological findings were also of special importance because of the accurate determination of the horizons of the fossils and of the recording of new localities and horizons for various algae and bryozoa. A second monograph, her geological guide to the western Dolomites, Geologisches Wanderbuch der westlichen Dolomiten, appeared in 1928. In the same year the University of Innsbruck conferred on her the diploma of honorary membership in recognition of her work in the Tyrol, and the Geological Survey of Austria nominated her an honorary correspondent ${ }^{39}$ Four years later the London Geological Society awarded her the Lyell Medal. She published over thirty original works, and her translation and abridgment of von Zittel's History of Geology and Palaeontology (1901) was another important contribution to the field.

Throughout her life Maria Gordon was rather painfully aware of the lack of interest of British geologists in her research, and from about 1907 onwards reported most of her studies in German-language journals. Writing to her Austrian friend and colleague Julius Pia in 1929 she said, 'In my own country I never count at all. I am made to feel a complete outsider.' She attributed her Lyell medal 'entirely to the previous generous treatment given me by your Geological Society'. Pia pointed out, however, that although she was correct in this opinion, the reason for her professional isolation at home was that no British geologists were familiar enough with the Dolomites to appreciate her work. Despite her unhappiness at the isolation, she could write in 1937, two years before her death, 'But the work was a joy and I look back on the days of expecting discovery at every corner as my happiest time. ${ }^{40}$ With nineteen technical articles to her credit before 1900 she was the most productive woman field geologist of the nineteenth century.

A person of exceptional energy and ambition, from her youth onwards she fought opposition from many quarters, family, universities and scientific circles, in what was a pioneering struggle for a scientific education and the right to follow the path of her choosing. In 1895 she had married $\mathrm{Dr}$ (later Professor) John Gordon, an Aberdeen physician, and they had two daughters and a son. From the time of her marriage she somehow found time not only for family responsibilities and geological research, but for social service in women's action groups as well. After John Gordon died in 1919 she moved with her children to London, where she took part in political activities as a strong Liberal supporter, in civic affairs (as a Justice of the Peace and later Chairman of the Marylebone Court of Justice), and in national and international women's organizations. Her work in the latter included the organization of the Council for the Representation of Women in the League of Nations in 1919. For these services she was awarded a DBE in 1935; the University of Edinburgh gave her an honorary LLD the same year. The long memorial written by Julius Pia and published in an Austrian journal after the outbreak of hostilities in 1939 is a particularly moving tribute to her life's work.

Catherine Alice Raisin (1855-1945), ${ }^{41}$ a Londoner and the daughter of a steward to the Inner Temple, was another pioneer among nineteenth-century women scientists and the

39 Ibid., 996.

40 See Pia, op. cit. (33), 184. The quotations are from Ogilvie Gordon's letters to Pia, and his reminiscences.

41 See the obituaries by Doris L. Reynolds, 'Dr. Catherine Alice Raisin', Nature (1945), 156, 327-8, L. H., Proceedings of the Geologists' Association (1946), 57, 53-4, and E. J. G., Quarterly Journal of the Geological Society (1946), 102, pp. xliv-xlv. 
first to take geology classes at University College. She also studied botany and zoology, taking a Special Certificate in botany in 1877 , a year before degrees were opened to women. Her B.Sc., with honours in geology and zoology, was awarded in 1884. After graduating she continued to work at University College for a number of years as voluntary assistant to T. G. Bonney, one of the distinguished figures in late nineteenth-century British geology. In 1890 she succeeded Grenville Cole as head of the Geology Department at Bedford College for Women, becoming the first woman to occupy the headship of a geology department in a British university. She held the post until her retirement thirty years later. Between 1890 and 1907 she was also in charge of the Botany Department, and she served as vice-principal from 1898 to 1901 . Her award of the Lyell Fund in 1893 marked the first time the Geological Society had given the honour to a woman; it had to be accepted for her by Bonney, since women were not at the time allowed to attend the Society's meetings. She received a London D.Sc. (geology) in 1898, the second given to a woman.

Most of Raisin's research was in microscopic petrology and mineralogy; she published twenty-four papers between 1887 and 1905, some in collaboration with Bonney. Included among them were reports of field and laboratory studies of rocks from western regions of the British Isles, the Ardennes and Switzerland, and accounts of the petrography of rock collections from the Himalayas and regions of Africa. An excellent microscopist, she used the most up-to-date techniques of the time. Her best known work was her careful and detailed investigation of the microscopic structure of serpentines; a joint paper published with Bonney in 1905 was of special interest. ${ }^{42}$ Also notable were her studies of the Cambrian series of North West Caernarvonshire, and her work on the metamorphic rocks of South Devon carried out mainly in the late 1880s; here she made one of the earliest attempts to map metamorphic facies.

When fellowship in the Geological Society was finally opened to women in 1919, Catherine Raisin was one of the first to be admitted. She was then sixty-four, however, and close to retirement. She belonged to the Geologists' Association (which had never excluded women) for sixty-seven years, and was latterly its most senior member. Like Ogilvie Gordon, she had always taken an active interest in all aspects of women's welfare and advancement. In the late 1870 s, while studying for her first degree, she founded and organized a discussion club for women - the Somerville Club - which flourished for several years until replaced by other educational amenities for women. Later, especially after she retired from teaching in 1920, she again took on extensive work in women's groups.

It was at Newnham College, Cambridge, however, rather than at University College, that the majority of the late nineteenth-century British women geologists trained. Cambridge then housed some of the country's most eminent geologists and stood out among British universities for its original and innovative research (at a time when such work was to a large extent being carried out by the government Geological Survey).

42 T. G. Bonney and Miss Catherine Raisin, 'The microscopic structure of minerals forming serpentine, and their relation to its history', Quarterly Journal of the Geological Society (1905), 61, 690-714. See also, Catherine A. Raisin, 'On the nature and origin of the Rauenthal serpentine', ibid. (1897), 53, 246-68; and (with T. G. Bonney) 'On varieties of serpentine and associated rocks in Anglesey', ibid. (1899), 55, 276-302. 
Furthermore, the Cambridge Natural Sciences Tripos curriculum in geology was especially successful, combining specialized work with a broad, integrated scientific training. ${ }^{43}$

Of the early Newnham College geologists, probably the most distinguished was Gertrude Lilian Elles (1872-1960) ${ }^{44}$ Born in the south but of half-Scottish parentage, Elles was an outstanding figure among women geologists. She entered Newnham in 1891 and studied under the guidance of Thomas McKenny Hughes and John Edward Marr, two of the leading geologists of the period. They gave her what she was later to characterize as 'sound knowledge of methods and routine in field work' ${ }^{45}$ She took first class in geology in Part II of the Natural Sciences Tripos in 1895.

Elles was a field geologist, stratigrapher, and palaeontologist; her major work concerned the interpretation of graptolite zones of Lower Palaeozoic strata. For the Ordovician and Silurian periods the graptolites have been used as the zonal markers of choice because their characteristic evolutionary pattern along a few dominant trends permitted determination of the age of the rocks, at least approximately, by the morphological nature of the fauna. The fossil graptolites themselves look, in most cases, like little more than pencil marks on a piece of shale, but their study is enormously complex. Following the work of Charles Lapworth in the 1870s and 1880s, Elles extended the interpretation of successive graptolite beds, working in the Welsh Borderland region and in the Lake District. Then, in the late 1890 s, she and her Newnham friend and colleague Ethel Wood began the preparation of British Graptolites, ${ }^{46}$ a monograph which was produced in parts over the next twenty years under the general editorship of Lapworth. Elles wrote the descriptive text and Wood prepared the illustrations. Commonly referred to as 'Elles and Wood', this monumental work, the product of years of strenuous field work and innumerable consultations of public and private collections, provided detailed descriptions of all the graptolite species and meticulously recorded their occurrence in successive beds. It was to be the basis of all subsequent research in the area for many years.

The body of detailed information which the monograph presented naturally gave rise to the question of whether a continuous evolutionary pattern could be traced within the graptolite group. In 1922 Elles presented the fundamental analysis of this biological and evolutionary question in a paper which summed up twenty years of work and set out her general and philosophical conclusions on the wide biological and geological significance of the graptolites. She analysed the evolutionary history of the entire group in terms of general trends and stressed their stratigraphical significance. ${ }^{47}$ Writing half a century later, in 1971, John Challinor noted that the zones established by Lapworth, Elles and Wood had remained the standard, clear proof of the outstanding quality of the work. Challinor

43 Porter, op. cit. (4), 835 .

44 Obituaries by W. B. R. K., Proceedings of the Geologists' Association (1961), 72, pt 1, 168-71, and by O. M. B. B[ulman], Proceedings of the Geological Society (1961), no. 1592, 143-5; see also John Challinor, The History of British Geology. A Bibliographical Study, New York, 1971, 187.

45 G. L. E[lles], obituary for Margaret Chorley Crosfield, Proceedings of the Geological Society (1953), no. 1502, pp. cxxxi-cxxxii.

46 G. L. Elles and E. M. R. Wood, British Graptolites, London, 1901-19.

47 G. L. Elles, 'The graptolite faunas of the British Isles', Proceedings of the Geologists' Association (1922), $33,168-200$. 
further concluded that the monograph, taken in conjunction with the work of Elles and Wood on the formations of the Welsh Borderland, probably constituted the most notable contribution 'for all time' by women geologists to British geology ${ }^{48}$ - a most remarkable accomplishment in the first pioneering generation of professional women geologists.

Elles wrote more than ten later papers on graptolites, but also published a number on Lower Palaeozoic stratigraphy. Indeed, although remembered mainly as a palaeontologist and an authority on the graptolites, her stratigraphic field studies were substantial. Her papers on the Ludlow formations, Builth and Bala, classic ground since the days of Adam Sedgwick, were among her most important. ${ }^{49}$ Fairly late in life she took up the study of metamorphic rocks of the Scottish West Highlands, at least in part because she was very fond of that region of the country. Her contributions included studies on metamorphism in relation to structure in the Highland succession.

She was without an official university position at Cambridge until 1926, when, under the Revised Statutes, she was appointed to a university lectureship. Ten years later, when she was sixty-four and soon to retire from her college posts, she became the first woman Reader. At Newnham she was successively lecturer, Fellow, vice-principal and honorary Fellow, and throughout her life the welfare of the College was one of her major concerns. An enthusiastic teacher, she had a strong influence on several generations of Cambridge geologists, men as well as women. She took a Dublin D.Sc. in 1907; forty-two years later Cambridge honoured her with an Sc.D. One of the first women to be admitted to the Geological Society, she became a Fellow in 1919 and served on the Council from 1923 to 1927. She had been awarded the Lyell Fund in 1900, and in 1919, following completion of the graptolite monograph, received the Murchison Medal. In 1923 she held national office as president of Section C of the British Association for the Advancement of Science. An active member of the British Red Cross Society for many years, she was commandant of a Red Cross hospital in Cambridge during the First World War; she received an MBE for her services.

Ethel Wood (Dame Ethel Shakespear) $(1871-1945)^{50}$ was the life-long friend and colleague of Gertrude Elles. Like Elles, as a student at Newnham College she came under the influence of Hughes and Marr. Her first work was a study of rocks in the Lake District, suggested by Marr and undertaken jointly with Elles. The results were published in the Geological Magazine in 1895. She took class I in geology in part II of the Natural Sciences Tripos examinations in $\mathbf{1 8 9 5}$ and stayed on at Cambridge for a further year, when, as a Newnham College research student, she began her study of the ancient rocks of the Welsh Borderlands, again in collaboration with Elles. In 1896 she went to Birmingham University as research assistant to Charles Lapworth. Two of her own publications from this period were especially important and provided considerable stimulus to workers on Lower

48 Challinor, op. cit. (44), 144-5.

49 See, for instance, the following: (with Ida L. Slater) 'The highest Silurian rocks of the Ludlow district', Quarterly Journal of the Geological Society (1906), 62, 195-221; 'The relation of the Ordovician and Silurian rocks of Conway (North Wales)', ibid. (1909), 65, 169-92; 'The Bala county: its structure and rock succession', ibid. (1922), 78, 132-68.

50 See the obituaries by G[ertrude] L[ilian] E[lles], Quarterly Journal of the Geological Society (1946), 102, pp. xlvi-xlvii, and Nature (1946), 157, 256-7. 
Palaeozoic rocks. The first was a 1900 paper on the Ludlow formations which clearly demonstrated the value of graptolites in the classification and mapping of the monotonous mudstones of the Silurian rocks. The second was her 1906 paper on the Tarannon series, virtually a small monograph on those beds, which made plain their stratigraphic relationship to the betrer-known Upper Llandovery horizon. ${ }^{51}$ The outstanding quality of her work was recognized in 1904 by the award of the Wollaston Fund from the Geological Society. The following year she was elected an Associate of Newnham College. She took a D.Sc. at Birmingham University in 1906, and shortly after that married G. A. Shakespear, a lecturer in physics. Their only child, a daughter, died in infancy.

Although she formally gave up her assistantship on marrying, Wood nevertheless continued to collaborate fully with Gertrude Elles on the graptolite monograph, carrying on with the work they had begun in the late 1890s. She became a Fellow of the Geological Society in 1919 and the following year, shortly after the last part of the monograph came out, was awarded the Murchison Medal. Throughout much of the First World War she undertook considerable national and regional work on behalf of wounded soldiers, and served for a number of years on one of the special committees of the Ministry of Pensions. For this public service she received an MBE in 1918 and a DBE in 1920. Despite the hope of her scientific colleagues that after the war she would give her time to geology, she instead took on more and more civic responsibilities, becoming a Justice of the Peace for Birmingham and, with the outbreak of the Second World War, working on increasing farm productivity.

Two other notable women geologists, Ethel Skeat and Margaret Crosfield, trained and worked together at Cambridge in the 1890s under the guidance of Hughes and Marr. Skeat ${ }^{52}$ (who in 1910 married Cambridge palaeontologist and geological librarian, Henry Woods) took first class in the Natural Sciences Tripos examinations in 1894 and then spent a year in Munich, studying palaeontology with von Zittel. ${ }^{53}$ Some of her most noteworthy papers were written in collaboration with Crosfield and published in the Geological Society's Quarterly Journal. The first (1896), on the geology of the neighbourhood of Carmarthen, became the basis of the Geological Survey's Carmarthen sheet memoir when that came to be written. A later one (1925), on the rocks of the Clwydian Range, was another short monograph of similar high standard.$^{54}$ She also carried out palaeontological work in Denmark which resulted in a substantial joint publication with the Danish geologist Victor Madsen. ${ }^{55}$ The Geological Society awarded her the Murchison Fund in 1908; she was elected a Fellow in 1919. Later becoming interested in physical and social geography, she published two monographs, The Principles of Geography (1923) and The Baltic Region (1932). Like Elles, she held a Dublin D.Sc.

51 Ethel M. R. Wood, 'The Lower Ludlow formation and its graptolite fauna', Quarterly Journal of the Geological Society (1900), 56, 415-92; 'The Tarannon series of Tarannon', ibid. (1906), 62, 644-99.

52 See the obituary by H[enry] W[oods], Proceedings of the Geologists' Association (1940), 57, 114.

53 See note 35.

54 See Margaret Chorley Crosfield and Ethel G. Skeat, 'On the geology of the neighbourhood of Carmarthen', Quarterly Journal of the Geological Society (1896), 52, 523-41; 'The Silurian rocks of the central part of the Clwydian Range', ibid. (1925), 81, 170-92.

55 Ethel G. Skeat and Victor Madsen, 'On the Jurassic, Neocomian and Gault boulders found in Denmark', Danmarks Geologiske Undersogelse (1898), Rekke 2, 8, 213 pp. 
Margaret Crosfield (1859-1952) ${ }^{56}$ was at Newnham College from 1890 until 1893, when her studies were interrupted by illness. On her return she received special permission to concentrate on geology only and made full use of the privilege, taking all the advanced courses and carrying out all the field work offered. As well as her notable research with Ethel Skeat, she carried out a collaborative study with Mary Sofia Johnston on the Wenlock limestone of Shropshire, a report of which appeared in the Proceedings of the Geologists' Association, in 1914. She also wrote a short account of the geology of Surrey for Charles Edgar Salmon's Flora of Surrey (1931). A member of the Geologists' Association from 1892 and of the Palaeontographical Society from 1907, she served for a time on the Councils of both of these bodies and was the Association's librarian from 1919 until 1923. The geology of her home area, the Reigate district in Surrey, was her special interest, and she twice led Geologists' Association excursions in the region, one in 1899 and one in 1911. She was a keen supporter of the Holmesdale Natural History Club, in whose Proceedings she published one or two geological notes during the $1890 \mathrm{~s}^{57}$

One other distinguished late nineteenth-century woman geologist who deserves special mention is Jane Donald (Mrs Longstaff) $(1856-1935),{ }^{58}$ a naturalist and invertebrate palaeontologist from Carlisle. Her career presents a clear example of the overlap of the two traditions - the 'amateur' and the 'professional' geologist with a background of university training. Donald was educated at the Carlisle School of Art, and so might be considered an amateur in that she had no formal training in geology. However, she developed remarkably clear insight into the principles of systematic palaeontology, and her scientific work, which continued for almost half a century, was recognized with honours and awards. She was never connected with any institution, but visited museums at home and abroad to find the type specimens she needed. Her 1885 paper in the Transactions of the Cumberland Association on carboniferous gastropoda was the first of a series of about twenty papers on palaeozoic gastropoda, ${ }^{59}$ most of which appeared in the Quarterly Journal of the Geological Society between 1887 and 1933. In 1898 she was given the Murchison Fund, becoming the second woman to receive an award from the Geological Society; she became a Fellow in 1919. An acknowledged authority on land and fresh-water mollusca, she was probably the only woman 'amateur' to receive recognition in the form of honours bestowed by the Geological Society before 1900 .

Gertrude Elles, Maria Ogilvie Gordon, Catherine Raisin and Ethel Wood, probably the four most outstanding of the British women geologists whose careers began before the turn

56 M[ary] S[ofia] J[ohnston], Proceedings of the Geologists' Association (1953), 64, 62-3; Elles, op. cit. (45); Newnham College Register, 1871-1971, i, 65.

57 See Margaret C. Crosfeld, 'The Tremadoc slates', Proceedings of the Holmesdale Natural History Club (1896-98), 11-22; 'Redhill and Merstham', ibid. (1896-98), 65-6.

58 See the obituaries by L. R. Cox in the Proceedings of the Geological Society (1935), 91, pp. xcvii-xcviii, and in the Proceedings of the Geologists' Association (1936), 47, 97.

59 Jane Donald, 'Notes on some Carboniferous gastropoda from Penton and elsewhere', Transactions of the Cumberland and Westmorland Association (1885), 9, 127-36. Included among her later writings were the following: 'Notes on the genus Murchisonia and its allies; with a revision of the British Carboniferous species, and descriptions of new forms', Quarterly Journal of the Geological Society (1895), 51, 210-34; 'A revision of the British Carboniferous Murchisoniidae, with notes on their distribution and descriptions of some new species', ibid. (1926), 82, 526-55; 'A revision of the British Carboniferous members of the family Loxonematidae with descriptions of new forms', ibid. (1933), 89, 87-122. 
of the century, all belonged to the group which had the benefits of university training and the closer social integration into main-stream science which this can afford. Of these four, only Elles and Raisin held salaried professional positions. Elles's university appointment at Cambridge did not come until 1926, however, when she was fifty-four, and for most of her career she was on the staff of a women's college, as was Raisin. Nevertheless, their formal training, specialized research, and life-long paid employment place both these geologists unequivocally in the ranks of the developing professional group. Maria Ogilvie Gordon (like Jane Donald Longstaff) was an independent research worker, living on family income and seeking nothing in the way of a paid position; her reward was in the work itself. In this respect, despite her up-to-date, advanced training and her life-long commitment to research, Ogilvie Gordon was following the older tradition of many of the 'amateur' geologists of the earlier decades of the century. Likewise much of Wood's notable work was done after she had married and given up her assistantship. However, the fact that Elles and Raisin occupied paid positions while Ogilvie Gordon and Wood did not is clearly irrelevant in any discussion of the scientific value of their work. Rigorous application and intensity of commitment, qualities that characterize 'professional' scientific research, need not always be associated with the holding of a full-time, paid position, ${ }^{60}$ and to a large extent the paid or unpaid status of these scientists reflected social norms of the time. These were such that married, middle-class women whose husbands could support them often did not take salaried positions. ${ }^{61}$

Even though they faced handicaps - marginal places in educational institutions and only partial acceptance in the scientific community - at least three in this collection of early women geologists (Elles, Ogilvie Gordon and Wood) succeeded in carrying out research in which they moved well beyond the stage of data collecting and contributed to conceptual developments in the field. These three were unusual people, however, being not only among the élite of women scientists but also especially prominent figures in public life; Ogilvie Gordon and Wood both received DBEs, and Elles an MBE. They clearly shared the strongly-felt obligation of middle-class women of their time to undertake public service work, ${ }^{62}$ but, in combining the latter with both family responsibilities and professional activities, both Ogilvie Gordon and Wood broke through the more common social pattern. ${ }^{63}$ Even when measured against the background of the new generation of college-

60 See David Elliston Allen, The Naturalist in Britain. A Social History, London, 1976, 111.

61 See Jane Lewis, Women and Social Action in Victorian and Edwardian England, Stanford, 1991, 6. But see also note 63 .

62 Lewis, op. cit. (61), 1-16; see also Jane Lewis, Women in England 1870-1950: Sexual Divisions and Social Change, Bloomington, 1984, 73-4.

63 The generalization that women faced a choice between marriage and a career, which holds for the late nineteenth and early twentieth centuries (Lewis, op. cit. (62), 73) would not appear to fit readily the lives of outstanding women research scientists. There are several instances from the period of successful husband-wife scientific reams, and a number of examples of ourstanding women who, like Ogilvie Gordon, Wood and the early Russian geologist, Mariia Pavlova (see below) had tolerant and sympathetic husbands, supportive of their wives' professional work. (For examples of teams see Marilyn Bailey Ogilvie, 'Marital collaboration. An approach to science', in Uneasy Careers and Intimate Lives. Women in Science 1781-1979 (ed. Pnina G. Abir-am and Dorinda Outram), New Brunswick, 1987, 104-25, and other essays in this collection; for another example of an outstanding early woman scientist whose work was independent of her husband's, see the discussion of Ida 
educated women of the 1890s, women who, with their newly won independence, were able to participate in many aspects of public life, ${ }^{64}$ the overall achievements of these early geologists make their lives exceptional. ${ }^{65}$

\section{THE PROMINENCE OF BRITISH WOMEN IN NINETEENTH- CENTURY GEOLOGY}

\section{The special position of Cambridge}

Two-thirds of the university-trained women geologists listed in Appendix 1 were students at Cambridge. Indeed, a high proportion of the notable early British women in the sciences as a whole were Cambridge-trained, ${ }^{66}$ a situation resulting in large part from two important factors. One was the opening of Girton and Newnham Colleges (in 1869 and 1871) about a decade before the founding of women's colleges at Oxford or the opening to women of University of London degrees. This was quickly followed by the establishment of a network of connections between the two Cambridge colleges and the leading girls' schools throughout the country. Newnham especially supplied the science teachers for these schools, which in turn sent to Cambridge a succession of capable and well-prepared students. ${ }^{67}$ Secondly, in several disciplines, including geology, the Cambridge Natural Sciences Tripos curriculum provided excellent opportunities and encouragement for original work, ${ }^{68}$ and the most talented of the women students responded.

As can be seen from the careers of Elles, Wood, Skeat and Crosfield, the two geologists Hughes and Marr had a strong influence on the women students of the early 1890s. Hughes, professor from 1872 to 1917, was the founder of the Sedgwick Museum, the

Smedley MacLean in Mary R. S. Creese, 'British women of the nineteenth and early twentieth centuries who contributed to research in the chemical sciences', BJHS (1991), 24, 275-305, especially 282-4.) The life of the English palaeobotanist Eleanor Reid (1860-1953) provides anorher instance of a very successful married early woman geological scientist. In fact, Reid entered the field through collaboration with her husband, having taught mathematics at Cheltenham Ladies' College before her marriage. After she was widowed in 1916 she continued on her own and became internationally known as an expert on Pleistocene and Tertiary seeds (obituary by W.N.E., Proceedings of the Geological Society (1954), no. 1515, pp. cxl-cxlii).

64 See Barbara Caine, Victorian Feminists, Oxford, 1992, especially 251.

65 Their many undertakings brought constant conflict though. Wood gave up her scientific work at age fortyeight, after the completion of the graptolite monograph, and from then on let public service take all her time; Ogilvie Gordon was for much of her life torn between the demands of public work she declined to turn aside and her hopes and plans for research. Pia, op. cit. (33), 183, quoted a number of her remarks on this conflict in her letters to him: (1922) 'I have been overwhelmed with outside work'; (1925) 'I am rather in despair about getting on with my work'; (1927) 'Endless work to do in several of the Women's Societies and have had no attempt at finding time for geology'; (1928) 'So many outside duties to attend to'; (1931) 'I am getting nothing done at present because there is a rush of meetings'; (1934) 'I am not particularly happy this winter as I have had no time to do any scientific work'; (1936) 'I keep toiling hard at public work, meetings of all kind, while knowing inwardly that it is geology in my heart that I wish to do'; and in 1938, a few months before she died, 'I cannot tell you how constantly I have had to work all summer and autumn over many public duties'.

66 Creese, op. cit. (63).

67 For a fuller discussion of the interaction at this period between the women's colleges at Cambridge and the leading girls' secondary schools see Creese, ibid., 299-301.

68 Porter, op. cit. (4), 835 . 
famous Cambridge school of geology. Marr, an expert on the Lower Palaeozoic rocks of the Lake District and Wales, came to Cambridge in 1881 and succeeded Hughes in 1917. Both men were widely recognized for their original work and inspiring teaching, and at a time when women students were still not routinely admitted to lectures and laboratories they welcomed them into theirs. ${ }^{69}$ Marr especially encouraged independent field work. As suggested below, there does not seem to have been a comparable group of women geology students anywhere else in the 1890s.

\section{Some international comparisons}

Outside Britain the main contributions by women to nineteenth-century geological research came from the Russian Empire and the United States, at least as far as can be deduced from entries in the Royal Society's Catalogue of Scientific Papers. Twenty-three pre-1901 papers were published by Russian women and one by a Polish worker; North Americans produced sixteen (Table 1).

The emergence of women geologists in Russia paralleled quite closely in time the appearance of the post-1880 university-trained women in Britain. All of the nineteenthcentury Russian women's work was published after 1875 and most of it in the late 1880 s and the 1890s, following the establishment, during the 1870s, of 'Higher Courses for Women' in many of the major Russian cities. In St Petersburg, Moscow and Kiev these quickly developed into full, four-year programmes, providing, during the late 1870s and early 1880 s, university-level education for thousands of Russian women, a situation unmatched anywhere else in Europe at the time. ${ }^{70}$ Organized and staffed by men who were on the faculties of local universities, many of them internationally known scholars, these courses set high academic standards. ${ }^{71}$ Furthermore their purpose was scholarship rather

69 M. D. Ball, a student at Newnham from 1908 to 1911 , left a sprightly description of Marr's lectures ('Newnham scientists', in A Newnham Anthology (ed. Ann Phillips), Cambridge, 1979, 76):

Dear Dr. Marr would come stamping into the lecture room, his gown streaming behind him, and cut and slice the country up with gusto. Glaciers streamed slowly down, rivers meandered or were beheaded, such 'noxious spors' as the Fens spread themselves, and only the ancient hills of his beloved Lakeland and Scotland remained to make habitable spots for decent folk. All the same we all panted joyfully after him, filling notebook after notebook with more or less legible writing.

70 Christine Johanson, Women's Struggle for Higher Education in Russia. 1855-1900, Kingston and Montreal, 1987, especially the introduction, 3-8 and ch. 4, 59-76; Ruth A. Dudgeon, 'The forgotten minority: women students in imperial Russia, 1872-1917', Russian History (1982), 9, 1-26, and 'Women and Higher Education in Russia, 1855-1905', Ph.D. dissertation, George Washington University, 1975, university microfilm no. 75-26000; Sophie Satina, Education of Women in Pre-revolutionary Russia (tr. Alexandra F. Poustchine), New York, 1960.

71 Instruction was provided by the men for little or no pay as the result of an extraordinary alliance between Russian academics and women students at the time. This alliance came about largely as follows: interest in higher education for women had begun in Russia during the social upheavals following the Crimean War (1853-56), and for a few years beginning in 1859 women were accepted, in increasingly large numbers, as auditors in university courses. In 1863, however, strong pressure from the government forced universities to expel women auditors, a move which generated great sympathy for the women, and, in many of the faculty, a sense of moral obligation to try to help them. For more than a decade little could be done; many Russian women went to western Europe, 
than career training, ${ }^{72}$ an emphasis which encouraged research among those who were especially talented and could afford to stay on for postgraduate-level work. Among the sciences, chemistry and the various branches of medical research attracted the greatest numbers of advanced women students, ${ }^{73}$ but those taking geology formed a noticeable group.

Of five Russian women geologists whose publications are indexed in the Royal Society Catalogue, three were especially noteworthy, Mariia Tsvetaeva (b. 1854), Evgeniia Solomko-Sotiriadis (1862-98) and Mariia Pavlova (1854-1938). ${ }^{74}$ Tsvetaeva studied at the Lubianskie courses for women in Moscow, concentrating on geology under S. N. Nikitin, and completed the science-mathematics programme in 1877 . Over the next twenty years, although supporting herself and her mother by working as a gymnasium teacher, she collaborated closely with Nikitin. The reports of her field studies, carried out during summers on foot along vast stretches of the Volga basin in central Russia, were largely incorporated into Nikitin's publications, but two substantial palaeontological monographs appeared under her own name in the Bulletins of the St Petersburg Geological Committee in 1888 and $1898 .{ }^{75}$ She was the first woman to serve on the Geological Committee, and not only was one of the few women geologists to participate in the work of the International Geological Congress held in St Petersburg in 1897, but had the honour of serving as a member of its Organizational Committee. Evgeniia Solomko-Sotiriadis completed studies at the Higher Courses for Women in St Petersburg in 1883, later studied with von Zittel in Munich, ${ }^{76}$ and in 1887 took a Ph.D. at the University of Zurich. Although she died at the age of thirty-six, she published two major monographs, on stromatoporoids and on Jurassic and Cretaceous corals, both complex and difficult fossil groups. ${ }^{77}$ Mariia Pavlova, the author of more than half of the pre-1901 publications by

especially Zurich, for university education (see Jan M. Meijer, Knowledge and Revolution. The Russian Colony in Zurich (1870-1873), Amsterdam, 1955; Hanny Rohner, 'Die ersten 30 Jahre des medizinischen Frauenstudiums an der Universität Zurich, 1867-1897', Zürcher Medizingeschichtliche Abhandlungen, Neue Reihe (1972), 89, 5-96; Johanson, op. cit. (70), 51-8). In 1873, however, the tsarist government, uneasy about student involvement in émigré revolutionary circles, ordered the Russian women students to leave Zurich. Three years later, the demand in Russia for women's courses having increased, these were once again officially authorized, and the men faculty came forward in large numbers to conduct them. All but the St Petersburg (Bestuzhevskie) courses were closed by the late 1880 s as a delayed result of the counter-reforms following the assassination of Alexander II, and from then until the changes made by Nicholas II in 1894, educational opportunities for women in Russia were very limited - once again there was an exodus to western Europe (see, especially, Johanson, op. cit. (70)).

72 Ibid., 74.

73 Unpublished data, but see Table 1 for numbers on the chemical sciences.

74 Nalivkin, op. cit. (35), especially 4-36.

75 Mariia Tsvetaeva, 'Cephalopodes de la section supérieure du Calcaire Carbonifère de la Russie centrale', [1888], Mémoires du Comité Géologique (1888-90), 5, 58 pp.; 'Nautiloidea et Ammonoidea de la section inférieure du Calcaire Carbonifèr de la Russie centrale', [1898], ibid., (1888-98), 8, 46 pp. (The Geological Commitree, founded in 1882, was about the equivalent of the British Geological Survey.)

76 See note 35 .

77 Evgeniia Solomko-Sotiriadis, '[Stromatopora des Devonishchen System Russlands]', Verhandlungen der Russisch-Kaiserlichen Mineralogischen Gesellschaft zu St. Petersburg (1887), 23, 1-48; 'Die Jura- und Kreidekorallen der Krim', ibid. (1888), 24, 67-231. Among early Russian and British women geologists, the majority were palaeontologists or biostratigraphers. Of the five Russian women whose nineteenth-century work is listed in the Royal Society Catalogue, the three most productive were palaeontologists. The prominence of women in this area persisted for many decades, at least in the former Soviet Union, the country which by the mid- 
Russian women geologists and the most distinguished member of the group, became internationally known for her work on fossil ungulates and her contributions to evolutionary theory.$^{78}$ Following studies at the Sorbonne in the early 1880 s, she worked at Moscow University's geological museum (of which she was later director), and from 1910 until 1917 taught at the Lubianskie Higher Courses for Women. After the October Revolution she became professor of palaeontology at Moscow University, and in 1925 was elected a corresponding member of the Soviet Academy of Sciences. ${ }^{79}$

In the United States the important early steps in the opening of higher education to women were the establishing of a number of independent women's colleges in the northeastern region of the country, starting with Vassar in 1865, and the acceptance of women, by about 1870 , in many of the state universities, especially the new, federal governmentassisted, land grant institutions. ${ }^{80}$ Geology, however, was included only marginally in the curricula of the women's colleges ${ }^{81}$ until a programme was established at Bryn Mawr by Florence Bascom in the mid-1890s. ${ }^{82}$ Bascom (1862-1945) was the one American woman who took an advanced degree in the field before the turn of the century and then went on to a productive research career.$^{83}$ After studying geology at a state university in the $1880 \mathrm{~s}$ (the University of Wisconsin, of which her father was president), she went to Johns

twentieth century, trained and employed most women geologists. A survey of about 2500 Soviet palaeontologists made in 1968 brought out the fact that more than half (abour 1500) were women. Furthermore, the most difficult and complex fossil groups were those most often studied by women; of 480 workers in the survey specializing in foraminifers (small, primitive protozoans), 400 were women, while of 180 people studying brachiopods (where the labour required is considerably less monotonous and demanding) 100 were men and 80 were women (Nalivkin, op. cit. (35), 5-6). Although the number of British women palaeontologists active around the turn of the century is too small to support generalizations about what sub-area they tended to cluster in, it is perhaps worth noting that Elles and Wood worked on the difficult graptolite group, and Ogilvie Gordon specialized in corals and algac.

78 Among Pavlova's most substantial pre-1901 contributions was her series, 'Études sur l'histoire paléontologique des Ongules en Amérique et en Europe', Bulletin de la Sociétié Impériale des Naturalistes de Moscou (1889), 2, 135-82; (1890), 3, 653-716; (1893), 6, 137-221; (1900), 13, 268-328. Pavlova was the wife of the eminent Russian geologist A. P. Pavlov.

79 Only two women were accorded this honour before Pavlova : the marhematician Sofia Kovalevskaia in 1889 and Marie Sklodowska Curie in 1907.

80 See Margaret W. Rossiter, Women Scientists in America. Struggles and Strategies to 1940, Baltimore, 1982, especially chs. 1 and 2, 1-50; Charlotte Williams Conable, Women at Cornell: The Myth of Equal Education, Ithaca, 1977; Louis Barber Arnold, Four Lives in Science. Women's Education in the Nineteenth Century, New York, 1984; Sally Gregory Kohlstedt, 'In from the periphery: American women in science, 1830-1880', Signs (1978), 4, 81-96.

81 See Margaret W. Rossiter, 'Geology in nineteenth-century women's education in the United States', Journal of Geological Education (1981), 29, 228-32.

82 Even then the Bryn Mawr administration was reluctant to proceed with developing a full geology department; the subject was thought of as having 'no wide appeal to women' (Ida H. Ogilvie, 'Florence Bascom, 1862-1945', Science (1945), 102, 320-1).

83 Arnold, op. cit. (80), 92-123. Bascom, however, was not the first woman to become a Fellow of the Geological Society of America. That honour went to Mary Emilée Holmes, elected in 1889, one year after the society was established. Holmes took at Ph.D. in zoology at the University of Michigan in 1888, writing a dissertation on the morphology of the septa of fossil rugose corals. Nevertheless her main interest was home mission work, and after 1888 she appears to have given most of her time to activities in the Presbyterian Church and the promotion of eduction for negro girls in the South (Who was Who in America, Chicago, 1943, i, 581-2; see also Eleanor S. Elder, 'Women in early geology', Journal of Geological Education (1982), 30, 287-93). 
Hopkins University in Baltimore (Ph.D., 1893) ${ }^{84}$ and subsequently was a field geologist with the US Geological Survey and professor at Bryn Mawr College. Although by the turn of the century a number of American women were studying geology at other institutions as well, the programme Bascom started at Bryn Mawr in the mid-1890s became one of the most notable in early geological training for women in the United States. Her publications constitute about half of the American contribution to nineteenth-century women's papers in geology. ${ }^{85}$ Except for three articles in speleology by a talented self-taught amateur from Missouri, Luella Owen, the rest of the American work listed in the Royal Society Catalogue consists of reports of undergraduate studies or semi-popular observational notes by women whose main interests were in other areas. ${ }^{86}$

Thus, by the late 1870 s, although restrictions and hurdles of various kinds assuredly remained, basic opportunities for formal training in geology were becoming available to women in at least some institutions in Britain, Russia and the United States. The question arises, why was the subject taken up by late nineteenth-century women students in Britain to a greater extent than anywhere else ${ }^{87}$ At least three factors, none of which is entirely independent of the others, would seem to have been involved: the first of these was a long background in Britain of women's interest and activity in the earth sciences; secondly there was the presence throughout the country during much of the second half of the century of many local scientific societies which accepted women members; thirdly, from the mid1860 s onwards, a number of the better secondary schools for girls offered instruction in the natural sciences, including the earth sciences.

84 Bascom was accepted at Johns Hopkins (as a special student) only after she had made a convincing case to the university's executive committee that she could not get the instruction she wanted in petrography anywhere else in the country. She worked to some extent in isolation, listening to lectures from behind a screen, much as Solomko had done in Munich in the 1880 s. Her Ph.D. was the first in any field that Johns Hopkins gave to a woman.

85 Many of Bascom's most important studies appeared as US Geological Survey reports, generally co-authored by her collaborators on the survey staff. She worked in the Piedmont region of Maryland, Pennsylvania, and parts of Delaware and New Jersey, and made notable contributions over the years to the somewhat heated controversy about the origin of the complex eastern Appalachian erosion surfaces.

86 In the United States from about 1830 onwards a few women served as technical illustrators, sometimes working as assistants to geologist husbands (see note 6 for mention of similar work by geologists' wives in Britain); probably the most notable were Orra White Hitchcock, Sarah Hall, Kate Andrews and Harriet Huntsman, who prepared drawings for Geological Survey reports and other technical publications. One or two American women of the period wrote popular instruction works in geology; Jane Kilby Welsh's Familiar Lessons in Geology and Mineralogy Designed for the Use of Young Persons and Lyceums appeared in 1832 and Miss D. W. Dodding's First Lessons in Geology in 1847 (see Michele L. Aldrich, 'Women in geology', in Women in Science. Righting the Record (ed. G. Kass-Simon and Patricia Farnes), Bloomington, 1990, 42-71). Similar popular writings by women authors appeared about the same time in Britain, for instance Maria Hack's Geological Sketches (1832). By mid-century public lectures on geology, such as those given at the Lowell Institute in Boston and in other large cities, were popular with American women (Rossiter, op. cit. (81), 229), but their interest in these does not appear to have led to original contributions in technical journals.

87 We have not attempted to set out the social circumstances and educational patterns that might suggest explanations for the very low participation of western European women other than the British in nineteenthcentury geological work. It is perhaps worth noting, however, that comparison of the data in Tables 1 and 2 brings out the remarkable fact that the two regions where the bulk of geological, and all other scientific research was being carried out (Germany-Austria and France-Belgium-The Netherlands) were those where participation by women was least (Scandinavia, where participation by men was also very low, is an exceptional case). 
The background of productive activity in geology by British women which stretched back to the early decades of the century was itself rooted in a very widespread interest in minerals and fossils among the upper and middle classes, women as well as men, which went back even earlier.$^{88}$ Geology was a popular hobby over an extended period, and interest was undoubtedly reinforced by the long series of exciting discoveries of the early nineteenth-century British 'amateur' geologists. It was a field where there clearly was action. Furthermore, the nature of much of the work at the time was such that an energetic and intelligent lay person could readily take part. Speaking of the process of strata identification by fossil content (work he had pioneered), William Smith wrote in 1818 that 'so rapidly and extensively has the science spread in the West that ladies in Wiltshire and parts adjacent where specimens of identification are numerous and obtained with facility have distinguished themselves by these aquirements $[s i c]{ }^{39}{ }^{89}$ Thus, even in the early years of the century, serious participation by women had developed to the point where a few (Benett, Anning and Graham, for example) made themselves visible in contemporary records. As Figure 1 illustrates, women's activities gradually increased, and by the 1860 s and late 1870s their contributions to the literature were noticeable. By that time the influence of provincial societies was becoming important. Although women were to remain firmly excluded from the national Geological Society until 1919, from about the middle of the century they could join the Geologists' Association, a non-segregated organization with amateur and professional members, which functioned to a large extent as a national geological society for amateurs. ${ }^{90}$ They were also welcomed by a number of local scientific societies (which were then providing a strong stimulus for geological work), in part because of the financial support they contributed with their membership fees. ${ }^{91}$ The fact that the provincial societies very often published their members' work underscores their special importance for the early women geologists; articles by Crane appeared in the publications of the Brighton and Sussex Natural History Society, the Belfast Naturalists' Field Club brought out work by Thompson, the Holmesdale Natural History Club published papers by Crosfield, and Donald's early articles came out in the Transactions of the Cumberland Association.

The third, and, arguably, the most immediate factor at the time leading girls to study the earth sciences at university level, was the presence of natural sciences in the curricula of the foremost girls' schools in the late nineteenth century - a point that has received only limited attention so far. ${ }^{92}$ Although academic standards in average girls' schools of the time

88 Phillips, op. cit (6), 108. See also Elizabeth Chambers Patterson, Mary Somerville and Cultivation of Science, 1815-1840, The Hague, 1983.

89 Smith's remarks were quoted in William Smith, his Maps and Memoirs (Thomas Sheppard, Hull, 1920, 217), and reproduced in Torrens, op. cit. (7), 12. Etheldred Benett was withour doubt one of the Wiltshire ladies to whom Smith was referring.

90 O'Connor and Meadows, op. cit. (4), 85. From the 1830s, women had also attended geology lectures at British Association meetings (Phillips, op. cit. (6), 200-7).

91 O'Connor and Meadows, op. cit. (4), 87.

92 See the discussion by Patricia Phillips (op. cit. (6), 241-8) of the findings of the four-year Taunton Commission of Inquiry into the state of English schools (1864-68), and also Felicity Hunt, 'Divided aims: the educational implications of opposing ideologies in girls' secondary schooling, 1850-1940', in Lessons for Life. The Schooling of Girls and Women, 1850-1950 (ed. Felicity Hunt), Oxford, 1987, 3-21, especially 6. Leading girls' 
were very low, this was not so in the best ones, those most likely to educate the select group of young women going on to advanced studies. These offered instruction in a remarkable variety of science subjects (frequently including geology, physical geography, chemistry and natural history), which were well taught and popular with the pupils.

The choice of science subjects made by women candidates taking Cambridge University entrance examinations in the late 1870 s provides a rather dramatic illustration of where their interests lay. A report of the results of the Cambridge Higher Local Examination for 1878 stated that 'about thirty' women took these examinations in science subjects, twentysix taking geology and physical geography, seven geology, twenty-three mathematics, twenty-one botany and nine chemistry. The highest number of passes with distinction (seven) was in geology and physical geography. ${ }^{93}$ An even more interesting report of Cambridge Local Examination results appeared in Nature the following March. ${ }^{94}$ After expressing considerable concern over the generally low standard of passing in science subjects (for boys and girls), the writer proceeded to give the following remarkable information: 'We do not become further consoled by the finding that 15 senior boys and 79 senior girls took zoology, 11 boys and 177 girls botany, 24 boys and 150 girls geology.' Noting that 'girls have no more right to a scientific training than boys', he continued with this reflection:

Most likely, however, boys and their teachers will seek to know more of the life and past history of the globe when they find that girls can really hold their own in and enjoy these studies, and look with amazement on men for being so un-willing to learn or teach them ... But evidently there is in secondary schools little belief in the educative and attractive power of the study of nature. Why is it not considered that mathematicians are fostered by neglect and hindrance? ... Really conservatism and unwillingness to take a little trouble are the enemies.

These results directly reflected the fact that, in contrast to the best of the girls' schools, the leading boys' schools of the time still clung tightly to a classical curriculum and allowed little time for science. ${ }^{95}$

There does not appear to be much evidence for an equivalent strong interest in geology among secondary school girls in the United States at the time or of widespread activity in the field by women amateurs; American women were slower to enter the field, few taking up the study of geology at universities until after the turn of the century. Likewise there is little indication (so far) of amateur activity in geology by women in Russia during the early years of the nineteenth century. However, the exceptional expansion in higher

schools of the time included the North London Collegiate School, under Frances Mary Buss, Cheltenham Ladies' College, under Dorothea Beale, a number of Quaker schools, and girls' schools in Brighton and Bristol. In the period after 1870 the number of academically sound girls' schools increased further; among their science mistresses were many of the earliest of the women trained at Newnham and Girton Colleges. See also Joyce Senders Pederson, 'School mistresses and headmistresses: elites and education in nineteenth century England', The Journal of British Studies (1978), 15, 135-62.

93 'Notes', Nature (1878, 15 August), 18, 423.

94 Ibid. (1879, 27 March), 19, 497.

95 Phillips, op. cit. (6), 238-41. See also Hunt, op. cit. (92), 8. Later Nature reports of Cambridge entrance examination results generally did not separate boys from girls, but a note in August of $1879(20,379)$ stated that five candidates passed with distinction in geology, and among these were Miss C. E. Cross of Cambridge and Miss M. A. Broadhurst of Liverpool College for Girls, as well as a candidate from Leeds whose name was withheld (and who was therefore most likely a girl). 
education for women in that country in the 1870 s and 1880 s (unmatched in western Europe or America) brought outstanding female students into geology as into other scientific fields.

\section{SUMMARY}

In geological research by women the British were outstanding throughout the nineteenth century. Their prominence during the earlier decades was part of a general and widespread interest in the subject in Britain. During the second half of the century their activities were further encouraged by the presence of a considerable number of flourishing provincial scientific societies which accepted women members. To the long-established general interest was added, by the 1860 s, the possibility of formal instruction in the earth sciences in a number of leading girls' secondary schools. These factors led to significant numbers of women studying geology when full university-level training became available to them from the 1870s onwards. Among the early women geology students were at least three, Gertrude Elles, Maria Ogilvie Gordon and Ethel Wood, who went on to make outstanding research contributions. The second most productive national group of nineteenth-century women geologists was that formed by the Russians. Their work began to appear in the geological literature in the $1880 \mathrm{~s}$, following the establishment in the late $1870 \mathrm{~s}$ of university-level courses for women in several of the major Russian cities. American women were slower to enter the field, few studying geology until after the turn of the century.

Appendix 1. List of British women active in nineteenth-century geology who had at least one publication in a scientific journal, or who published a technical monograph, between 1800 and 1900

Notes

(a) For completeness, the names of those discussed in the text and the locations where they lived or worked are repeated here. Those names are marked with an asterisk ("). Some entries include additional biographical information not given in the text. For entries in which no source is referred to, the information given came from notes in technical papers.

(b) The superscript, $\mathrm{u}$, following a name indicates that the person so designated is known to have had formal university training in geology.

(c) In square brackets are given: (1) number of publications up to 1900; (2) area of interest; (3) time-span for appearance of publications.

"AnNing, Mary Ann ${ }^{96}$ (1799-1847). Lyme Regis. [1; palaeontology; 1839.]

"BENETT, Etheldred Anna Maria ${ }^{97}$ (1776-1845). Warminster, Wiltshire. [2; palaeontology; 1816-31.]

"CARne, Elizabeth Catherine Thomas ${ }^{98}$ (1817-73). Penzance. Author, and head of bank of Batton, Carne and Carne (Penzance) from 1858 to 1873 . Built mineral museum in

96 See note 11.

97 See note 7.

98 See note 29. 
Penzance and several schools in the area. [3, of which 2 were published posthumously; tectonics; $1860-78$.]

Corgnou, Caroline Pauline Marie ${ }^{99}(1865-1932)^{4}$. Cambridge. Entered Newnham College in 1887 from Manchester High School as Clothworkers' Scholar; Nat. Sci. Trip. Pt 1 Cl. III 1890; MA, Trinity College, Dublin. Assistant mistress at Pendleton High School 1890-94 and at Manchester High School 1894-1910; West Riding Education Department examiner 1910-18, inspector of secondary schools 1918-27. [1; palaeontology; 1890.]

"Crane, Agnes ${ }^{100}$ (b. 1852). Brighton. Also published on topics in natural history. [8; palaeontology; 1877-95.]

"Crosfield, Margaret Chorley ${ }^{101}$ (1859-1952)". Cambridge and Surrey. [4; stratigraphy; 1896-1900.]

Dale, Elizabeth ${ }^{102}$ (b. 1868) ${ }^{u}$. Cambridge. Entered Girton College in 1887 from Owens College, Manchester; Nat. Sci. Trip. Pt II Cl. II 1891. Pfeiffer Research Student 1898-1900; research in Cambridge botanical laboratory 1898-1914; also assisted for a time as demonstrator (botany) in Balfour laboratory; Garden Steward (Girton) 1912-17. Journal publications mainly in botany; also published the monograph, Scenery and Geology of the Peak of Derbyshire (1900). [1, joint with palaeobotanist A. C. Seward; palaeobotany; 1900.]

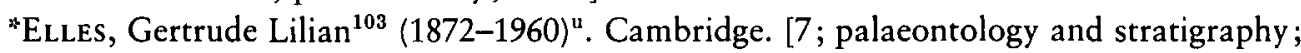
1895-1900.]

"EYTON, Charlotte. ${ }^{104}$ Shropshire. [7; various topics; $\left.1866-70.\right]$

Foley, Mary Cecilia ${ }^{105}$ (d. 1925) ${ }^{u}$. Student at University College London, under T. G. Bonney; Morris Prize in geology, 1891; B.Sc., honours geology, University of London, 1891; joined Geologists' Association 1892, and served on its Council, 1897-1900 and 1909-12, second woman to do so; held post at University of London; devoted much time to social work and women's causes; published one later geological paper (1901). [1; petrology; 1896.]

Forster, Mary. London. Co-worker of William Topley at the Geological Survey, and lecturer in geology at Bedford College for Women in the mid-1880s. [1, joint with Topley; 1887 .]

Gardiner, Margaret Isabella ${ }^{\mathbf{1 0 6}}(1860-1944)^{\mathrm{u}}$. Cambridge. Entered Newnham College in 1883 from Bedford College for Women; Drapers' Scholar 1884; Nat. Sci. Trip. Pt II Cl. II 1887; Bathurst Student at Newnham 1887-88; Associate of Newnham 1901-14; assistant mistress at St Leonards School for Girls, St Andrews, for about four years after leaving Newnham, then headmistress at Withington High School (1892-96) and

99 Newnham College Register, 1871-1971, i, 92.

100 See note 31.

101 See note 56.

102 Girton College Register, 1869-1946, i, 43.

103 See note 44.

104 See note 29.

105 E. W., Proceedings of the Geologists' Association (1926), 37, 229.

106 Newnham College Register, 1871-1971, i, 79. 
founder and first headmistress of Aldeburgh High School (1896-1907). [2; stratigraphy and mineralogy; 1888-90.]

"Graham, Maria Dundas (Lady Callcott) ${ }^{107}$ (1785-1842). London. [1; tectonics; 1824.]

Hart, J. B. (Mrs W. E.). India. Published five papers on topics in natural history in the Journal of the Bombay Natural History Society. [1; palaeontology; 1886.]

"Hastings, Barbara, Marchioness of ${ }^{108}$ (1810-58). Near Lymington, Hampshire. [3; palaeontology and stratigraphy; 1847-53.]

"Hodgson, Elizabeth ${ }^{\mathbf{1 0 9}}$ (1814-77). Lancashire. Also published on the botany of the Lake District. [8, including one published posthumously; palaeontology, glaciology and other topics in geology of Lancashire; 1863-78.]

Hughes, Mary Caroline. ${ }^{110}$ Cambridge. Daughter of Rev. G. F. Weston, honorary Canon of Carlisle; married Thomas McKenny Hughes, professor of geology ar Cambridge, in 1882; co-authored with her husband the monograph Cambridgeshire (1909). [1; palaeontology; 1888.]

Kelly, Agnesu. Oxford. Co-worker of H. A. Miers; published one other mineralogical paper in 1901. [1; mineralogy; 1900.]

LEE, Sarah Wallis Bowdich"11 (1791-1856). London. Daughter of J. E. Wallis of Colchester, Essex; contributed articles on various topics in natural history, including observations of animal life made during a stay in Africa, to the Magazine of Natural History; also wrote a number of popular books on natural history, and a biographical work, Memoirs of Baron Cuvier (1833). [1; palaeontology; 1831.]

"Longstaff, Mary Jane (née Donald)"112 (1856-1935). Carlisle. [10; palaeontology; 1885-1900.]

M'Kean, Minnie. Edinburgh. Member of the Edinburgh Naturalists' Society. [1; palaeontology; 1891.]

"Ogilvie Gordon, Maria Matilda (Dame Maria Gordon) ${ }^{113}$ (1864-1939)". Aberdeen, London and Munich. [19; tectonics, stratigraphy and palaeontology; 1892-1900.]

"RaIsIN, Catherine Alice ${ }^{114}$ (1855-1945)". University College London, and Bedford College for Women, London. [21; petrology; 1887-99.]

Scotr, S. (Mrs). Liverpool? Published one paper in the Journal of the Liverpool Geological Association. [1; 1891.]

"SKEAT, Ethel Gertrude (Mrs Woods) ${ }^{115}$ (d. 1939)". Cambridge. [2; stratigraphy and palaeontology; 1896-98.]

SolLAS, Igerna Brünhilda Johnson ${ }^{116}(1877-1965)^{\mathrm{u}}$. Cambridge. Younger daughter of William Johnson Sollas, professor of geology at Oxford. Student at Newnham,

107 See note 18.

108 See note 24.

109 See note 29.

110 See obituary for T. McKenny Hughes, Geological Magazine (1917), 54, 334-5.

$111 D N B, x i, 820$.

112 See note 58 .

113 See note 33.

114 See note 41.

115 See note 52.

116 Newnham College Register, 1871-1923, Staff, i, 9. 
1897-1901, Gilchrist Scholar; Nat. Sci. Trip. Pt II (zoology) Cl. 1; Bathurst student and demonstrator 1901-02; lecturer in zoology 1903-04, 1906-13; College Research Fellow 1904-06; Associate 1902-13. Collaborated with her father in work of determining internal structures of fossils and on methods of separation of minerals for chemical analysis; published two more papers on palaeontology (1901 and 1903) as well as reports of zoological research. [1; palaeontology; 1900.]

"Thompson, Sydney Mary (Mme Christen) ${ }^{117}$ (d. 1923). Northern Ireland. Married a Swiss artist, Rodolphe Christen, in 1900; continued to publish until at least 1906. [11; Irish glaciology; 1894-1900.]

"Wood, Ethel Mary Reader (Dame Ethel Shakespear) ${ }^{118}(1871-1945)^{4}$. Cambridge and Birmingham. [3; palaeontology; 1895-1900.]

\section{Appendix 2. The Royal Society Catalogue of Scientific Papers, 1800-1900; some statistical studies}

The bibliographical information on which this study is based was assembled by making a collection of the papers by nineteenth-century women geologists indexed in the Royal Society Catalogue. The possibility of the presence of some peculiarity in the Royal Society's selection process that would lead to a disproportionate representation of work by British geologists in general, and thence of work by British women geologists, seemed worth looking into.

We therefore examined a random sample of catalogue entries, looking for bias towards articles which appeared in English-language journals. The results, from a sample of size 2310 , are shown in Table 2, column 1 . As would have been expected from the well-known pre-eminence of France and Germany in nineteenth-century scientific research, articles published in French and German journals significantly outnumbered those in British journals (and those in American journals). There is no evidence for bias towards British journals in the Royal Society's selection process, and no reason to conclude that the work of British scientists is disproportionately represented. ${ }^{119}$

The possibility remains that the pre-eminence of British women in geology might have been part of a pattern of outstanding research productivity just in geology for the British in general. Examination of the geographical distribution of the geology papers in the random sample, however, provided no evidence for such a pattern (see Table 2, column 2); the sequence of data values for geology papers reflects reasonably closely that for scientific papers in all fields. While British geologists were indeed notably productive, their nineteenth-century publication output did not surpass that of the two regional groupings, France-Belgium-The Netherlands, and Germany-Austria. The pre-eminence of the British women, who produced 65 per cent of women's papers in geology, cannot, therefore, be seen simply as part of an overall pattern of exceptional productivity of British workers in geology.

117 See note 31.

118 See note 50.

119 Some authors published in journals other than those of their own countries, particularly German journals. However, checks of the nationalities of authors in the random sample entries suggest that this factor has no significant effect on the conclusions drawn here. 
Table 2. Country or region of journal publication for the random sample of all papers, and for the geology papers therein; from the Catalogue of Scientific Papers. (A) 1800-80; (B) 1881-1900

\begin{tabular}{lcc}
\hline \hline & $\begin{array}{l}(1) \\
\text { No. of papers } \\
\text { in sample of } \\
\text { all papers }\end{array}$ & $\begin{array}{l}\text { No. of } \\
\text { geology papers } \\
\text { in this sample }\end{array}$ \\
\hline Region & $250(23 \%)$ & $25(21 \%)$ \\
Britain, Ireland & $297(27 \%)$ & $30(25 \%)$ \\
France, Belgium, The Netherlands & $319(29 \%)$ & $39(32 \%)$ \\
Germany, Austria & $57(5 \%)$ & $3(2 \%)$ \\
Italy & $30(3 \%)$ & $1(1 \%)$ \\
Russia, Poland & $19(2 \%)$ & $3(2 \%)$ \\
Scandinavia & $60(5 \%)$ & $12(10 \%)$ \\
USA, Canada & $59(5 \%)$ & $8(7 \%)$ \\
Other & 1091 & 121 \\
Total & $213(17 \%)$ & $27(22 \%)$ \\
Britain, Ireland & $280(23 \%)$ & $34(28 \%)$ \\
France, Belgium, The Netherlands & $390(32 \%)$ & $28(23 \%)$ \\
Germany, Austria & $80(7 \%)$ & $3(2 \%)$ \\
Italy & $47(4 \%)$ & $7(6 \%)$ \\
Russia, Poland & $19(2 \%)$ & $5(4 \%)$ \\
Scandinavia & $124(10 \%)$ & $11(9 \%)$ \\
USA, Canada & $66(5 \%)$ & $8(7 \%)$ \\
Other & 1219 & 123 \\
Total & & \\
\hline \hline
\end{tabular}

Procedures for taking the sample. Each item drawn for the sample is a paper indexed in an entry in the Catalogue of Scientific Papers. Some of these catalogue entries are complex, listing, for example, more than one place of publication for a given paper, or even several different papers with the same title. For the drawing of the sample, publications listed in the catalogue having the same authors, title and year were distinguished from each other by journal, volume, or page run, and each such publication was given approximately the same probability of being chosen.

In the first twelve volumes the sample was drawn by first selecting equally spaced pages (every tenth page of the catalogue) and then on each such page randomly selecting one item. This gave approximately one sample entry for every 415 selectable publications listed in the catalogue. (The latter figure was established as follows: on every hundredth page the number of selectable publications was counted; the mean for 118 pages was 41.51 with standard deviation 6.88. Hence, taking one sample item on every tenth page, we have one sample entry per 415 catalogue entries.) In the last seven catalogue volumes (xiii-xix) the number of entries per page is substantially greater than in volumes i-xii, because of smaller type size. Therefore, to keep approximately the same probability of selecting any given item, the interval between pages was adjusted so that one publication was taken from each of 16 pages in every 100 pages. This gave one sample item for every 425 publications listed 
in volumes xiii-xix. (Again, a count of entries on every hundredth page was taken; the mean for 70 pages was 67.99 selectable publications, standard deviation 12.53. Taking sixteen sample items from every 100 pages gave one sample item per $425=67.99 \times 100 / 16$ catalogue entries.) The pages selected in these volumes were as evenly spaced as possible, either six or seven pages apart. The number of the starting page and thereafter the positions of publications on the selected pages were taken from successive suitable pairs of digits in a list of random digits. 